\title{
Revised mineral dust emissions in the atmospheric chemistry-climate model EMAC (MESSy 2.52 DU_Astitha1 KKDU2017 patch)
}

\author{
Klaus Klingmüller $^{1}$, Swen Metzger ${ }^{2,4}$, Mohamed Abdelkader ${ }^{1,3}$, Vlassis A. Karydis ${ }^{1}$, Georgiy L. Stenchikov ${ }^{3}$, \\ Andrea Pozzer ${ }^{1}$, and Jos Lelieveld ${ }^{1,2}$ \\ ${ }^{1}$ Max Planck Institute for Chemistry, P.O. Box 3060, Mainz, Germany \\ ${ }^{2}$ The Cyprus Institute, P.O. Box 27456, Nicosia, Cyprus \\ ${ }^{3}$ King Abdullah University of Science and Technology, Thuwal, Saudi Arabia \\ ${ }^{4}$ ResearchConcepts io GmbH, Freiburg im Breisgau, Germany
}

Correspondence: Klaus Klingmüller (k.klingmueller@ mpic.de)

Received: 4 July 2017 - Discussion started: 17 July 2017

Revised: 23 November 2017 - Accepted: 2 February 2018 - Published: 16 March 2018

\begin{abstract}
To improve the aeolian dust budget calculations with the global ECHAM/MESSy atmospheric chemistryclimate model (EMAC), which combines the Modular Earth Submodel System (MESSy) with the ECMWF/Hamburg (ECHAM) climate model developed at the Max Planck Institute for Meteorology in Hamburg based on a weather prediction model of the European Centre for Medium-Range Weather Forecasts (ECMWF), we have implemented new input data and updates of the emission scheme.

The data set comprises land cover classification, vegetation, clay fraction and topography. It is based on up-todate observations, which are crucial to account for the rapid changes of deserts and semi-arid regions in recent decades. The new Moderate Resolution Imaging Spectroradiometer (MODIS)-based land cover and vegetation data are time dependent, and the effect of long-term trends and variability of the relevant parameters is therefore considered by the emission scheme. All input data have a spatial resolution of at least $0.1^{\circ}$ compared to $1^{\circ}$ in the previous version, equipping the model for high-resolution simulations.

We validate the updates by comparing the aerosol optical depth (AOD) at $550 \mathrm{~nm}$ wavelength from a 1-year simulation at T106 (about $1.1^{\circ}$ ) resolution with Aerosol Robotic Network (AERONET) and MODIS observations, the $10 \mu \mathrm{m}$ dust AOD (DAOD) with Infrared Atmospheric Sounding Interferometer (IASI) retrievals, and dust concentration and deposition results with observations from the Aerosol Comparisons between Observations and Models (AeroCom) dust bench-
\end{abstract}

mark data set. The update significantly improves agreement with the observations and is therefore recommended to be used in future simulations.

\section{Introduction}

Aeolian dust can impair everyday life and air quality especially in severe dust storms. Due to the worldwide presence of dust sources and through long-range transport, it has a significant global impact on atmospheric radiation transfer and air quality, affecting climate (IPCC, 2014) and human health (Giannadaki et al., 2014), which requires detailed representation in general circulation models (Shao et al., 2011).

Global models have different requirements regarding the dust emission scheme compared to regional models. As global models require planetary consistent input data sets, the availability of adequate data is more limited. Additionally, the coarser grid spacing requires an appropriate parameterisation of subgrid processes, and, for example, reproducing individual dust events with global models may have lower priority than adequately representing the atmospheric dust budget on a longer timescale. However, with their everincreasing resolution, global models in many regards correspond to former-generation regional models, and therefore established emission schemes are often applied in both regional and global models. 
Global models implement dust emissions with various complexity levels. Even in the simplest version, prescribed (offline) dust emissions can produce acceptable results for the global aerosol distribution and variability due to the importance of atmospheric transport (Pozzer et al., 2015; Pringle et al., 2010b). Improved agreement with observations is generally achieved with online emission schemes which consider actual meteorological conditions, most importantly the surface friction velocity and the wind speed close to the surface. They are combined with a characterisation of surface properties, where properties and relations are to different degrees empirical (source functions) or deduced from microphysical processes. The dominant processes considered are saltation bombardment by sand blasting and aggregate disintegration, and more elaborate emission schemes consider additional effects such as direct aerodynamic entrainment (Shao, 2001; Klose et al., 2014). The inability of most current global models to resolve convection means that haboobs, which are responsible for a major fraction of the dust emissions (Marsham et al., 2013; Allen et al., 2013, 2015), are not represented at all. Therefore, efforts are made to combine the emission schemes with explicit parameterisations of convective dust storms (Pantillon et al., 2015, 2016).

The global ECHAM/MESSy atmospheric chemistryclimate model (EMAC) (Jöckel et al., 2005, 2010), which combines the Modular Earth Submodel System (MESSy) with the ECMWF/Hamburg (ECHAM) climate model developed at the Max Planck Institute for Meteorology in Hamburg based on a weather prediction model of the European Centre for Medium-Range Weather Forecasts (ECMWF), provides a choice of dust emission schemes (Tegen, 2002; Balkanski et al., 2004; Astitha et al., 2012) to calculate the emission flux online based on the meteorological conditions.

An advanced scheme producing convincing results when compared to observations has been presented by Astitha et al. (2012), building on previous studies (Pérez et al., 2006; Spyrou et al., 2010; Laurent et al., 2008; Laurent et al., 2010; Marticorena et al., 1997; Zender et al., 2003; Tegen, 2002), and is the basis of the work presented here. Its basic principles are shared with emission schemes used in many other models (e.g. Zender et al., 2003; Jones et al., 2012; Albani et al., 2014; Huneeus et al., 2011), but alternative approaches exist (e.g. Shao, 2001; Kok et al., 2014). The emission scheme combines meteorological parameters with descriptions of land cover type, clay fraction of the soil and vegetation cover. One variant of the scheme (DU_Astitha2) additionally accounts for regional differences of the particle size distribution, while in the present study we focus on the simpler variant DU_Astitha1, which achieves competitive results with reduced complexity (Astitha et al., 2012) and has proven to perform well in previous studies (Abdelkader et al., 2015; Abdelkader et al., 2016). The emission scheme is summarised in Appendix A.

The emission scheme applies physical principles in the sense that the governing equations are derived for microphys- ical processes that are consistently applied globally without the option to adjust the resulting emissions regionally. In this study, we extend the emission scheme by including a topography factor while we strictly adhere to the global consistency concept and refrain from using regional tuning factors.

Though generally the original emission scheme produces convincing results, some shortcomings, predominantly related to the input data, have become apparent recently and are the motivation for the revision presented in this study. The original input data for land cover and vegetation are based on observations from the early 1990s and are thus dated in view of the rapid changes of deserts and semi-arid regions in recent decades (Figs. 1, 2, Klingmüller et al., 2016; Lamchin et al., 2016; Dong and Sutton, 2015). For instance, the emission mask resulting from the land cover data considerably limits emissions in the Middle East, essentially not allowing dust emissions in Syria and northern Iraq. This is in conflict with the emergence of severe dust outbreaks from that region (Solomos et al., 2017) and the strong link between the soil conditions in that region and trends of atmospheric dust over the Middle East (Klingmüller et al., 2016). Moreover, only a static land cover map and a single seasonal cycle for the vegetation index was provided.

As a consequence, the effect of variations and trends of these quantities on the modelled dust emissions has been excluded. Further, the resolution of the original input data is limited to $1^{\circ}$. Particularly for EMAC simulations focusing on dust modelling, high model resolutions are desirable, considering how localised dust outbreaks can occur. In the long term, the resolution of global models will approach the resolution of today's regional models where high-resolution input data are essential to include details of dust generation patterns (Shi et al., 2016; Anisimov et al., 2017). For model resolutions higher than $\mathrm{T} 106\left(\approx 1.1^{\circ}\right)$, as applied in the present study, improved input data are required to justify the numerical effort. To equip the model for simulations at a resolution of T255 $\left(\approx 0.5^{\circ}\right)$ or higher, new input data should have at least $0.1^{\circ}$ resolution.

In addition to updated input data addressing these issues, we present adjustments to the emission scheme to assure that the updated input has no undesirable effects, such as toostrong emissions in mountainous regions, and to further improve the performance of the scheme.

To quantify the impact of the updates, we compare a validation simulation with the reference simulation, the latter using the original emission scheme and data. Results and comparisons of other schemes in EMAC are provided elsewhere (Gläser et al., 2012; Astitha et al., 2012). The purpose of the validation is to demonstrate the advantages of the updates and to test the results so that the modifications can swiftly be adopted by the community; more applications and in-depth analysis thereof are beyond the scope of this mostly technical study.

The article is structured as follows: in Sect. 2, we introduce and discuss the updated input data; the modifications to 
Land cover mask trend

(a) (Kendall rank correlation coefficient)

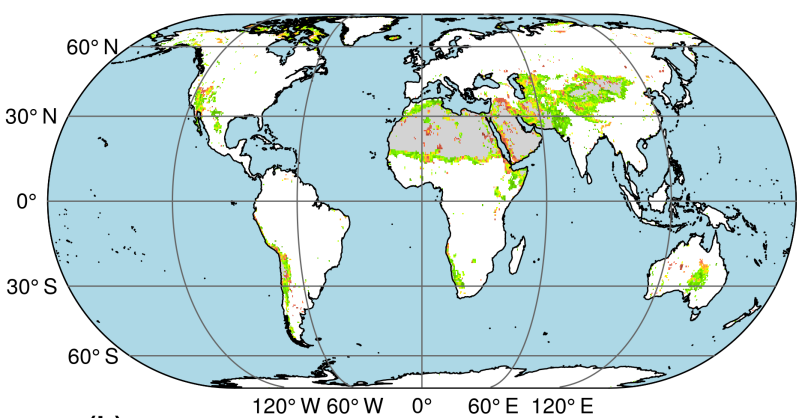

(b)

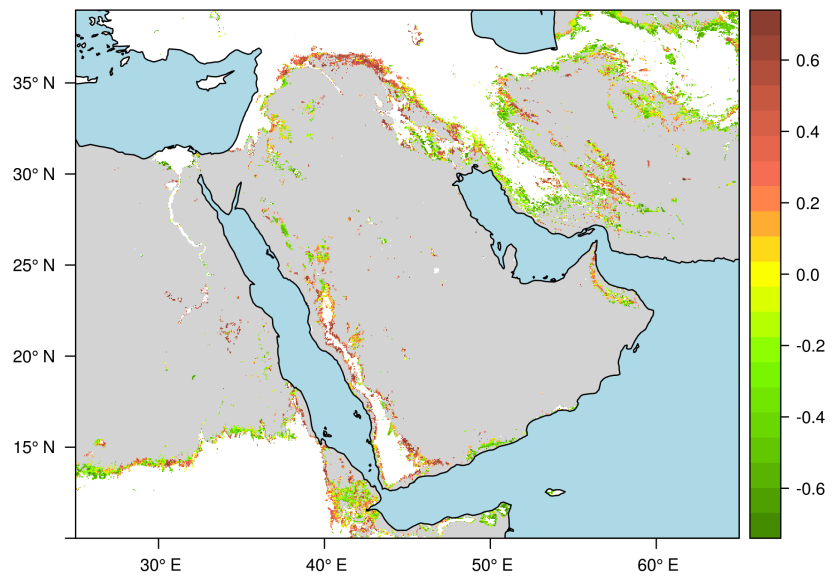

Figure 1. Trend of the dust emission mask based on the Moderate Resolution Imaging Spectroradiometer (MODIS) MCD12C1 land cover product during the period 2001 to 2012 . Regions with changing surface properties are coloured according to the Kendall rank correlation coefficient $\tau$ of time and mask value, depicting expansion of source regions (i.e. positive correlation coefficients) in red and contraction in green. Regions where the land cover remained unchanged are grey (source regions) or white (non-source regions). For better readability, in the global plot (a) the values have been averaged over $10 \times 10$ pixels ignoring constant pixels. The magnified plot of the Middle East (b) shows the original $0.05^{\circ}$ pixels.

the EMAC code are presented in Sect. 3, and their individual effects studied in Sect. 4. The effect of both is validated in Sect. 5 through comparison with the reference simulation, as well as ground-based aerosol optical depth (AOD) observations (Sect. 5.1), and satellite-based AOD (Sect. 5.2) and dust AOD (DAOD) (Sect. 5.3) retrievals as well as concentration and deposition data (Sect. 5.4).

\section{Updated input data}

\subsection{Land cover}

To replace the land cover classification map of Olson (1992), we use the Moderate Resolution Imaging Spectrora- diometer (MODIS) MCD12C1 land cover product (MODIS $\mathrm{MCD} 12 \mathrm{C} 1,2016)$ at $0.05^{\circ}$ resolution, allowing for dust emissions from regions classified as "barren or sparsely vegetated". Not only is the resolution higher than for the Olson data, which in the original emission scheme have been used at $1^{\circ}$ latitude and longitude (aggregated from $10^{\prime}$ ), but also yearly updated data from 2001 to 2012 are provided, also expecting more recent updates to become available. Therefore, changes of the land cover, for example, due to desertification, are taken into account, which have not been considered previously. To assess these changes, we compute for each pixel the Kendall rank correlation coefficient $\tau$ of annual mask value, which can be either 0 (non-emitting) or 1 (emitting), and time; the result is shown in Fig. 1. Positive values of $\tau$ indicate an expansion of source regions to the respective pixel; negative values indicate a disappearance of sources. In some regions, the deserts are shrinking, e.g. in the Sahel, central Asia and Australia. Expanding source areas are found rather centrally in the dust belt, e.g. in the Sahara, on both sides of the Red Sea and north of the Arabian Peninsula in Syria and Iraq. Globally, the area with positive correlation coefficients covers $1.3 \times 10^{6} \mathrm{~km}^{2}$, which is about half the area with negative correlation coefficients $\left(2.6 \times 10^{6} \mathrm{~km}^{2}\right)$. Additionally, the regions of shrinking deserts are spread over a larger area because, unlike the centrally located expanding source regions, they are predominantly surrounding the large deserts.

\subsection{Vegetation}

Yuan et al. (2011) have reprocessed the MODIS leaf area index (LAI) products to provide a temporally continuous and spatially consistent LAI data set for climate modelling that encompasses the time period starting from 2000. We have aggregated these data from $30^{\prime \prime}$ to $0.1^{\circ}$ spatial resolution and from 8-day to 1-month temporal resolution. The data replace the 12-month seasonal cycle of the vegetation area index with $1^{\circ}$ resolution based on the work of Kergoat et al. (1999) and Bonan et al. (2002). Using continually updated monthly values instead of a repeating seasonal cycle implies that multiannual vegetation trends are taken into account.

The LAI data are used to compute the vegetation factor (Astitha et al., 2012),

$f_{\text {veg }}=1-\frac{\min (\text { LAI, } 0.35)}{0.35}$,

which linearly interpolates between full emissions for no vegetation and entirely suppressed emissions for $\mathrm{LAI} \geq 0.35$, which was introduced as a threshold by Mahowald et al. (1999). The 16-year average, standard deviation of the yearly averages and the trend of the vegetation factor are shown in Fig. 2. The trend has been calculated as the slope of a linear regression model fitted to the annual averages using least squares; only pixels with $p$ values below the significance level of 0.05 are plotted. As demonstrated by the standard deviation plot, large variability and trends, e.g. related 


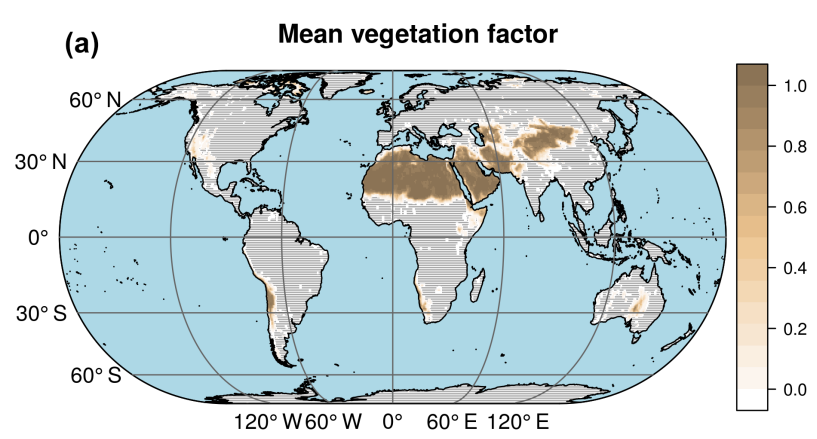

(b) Standard deviation of yearly vegetation factor

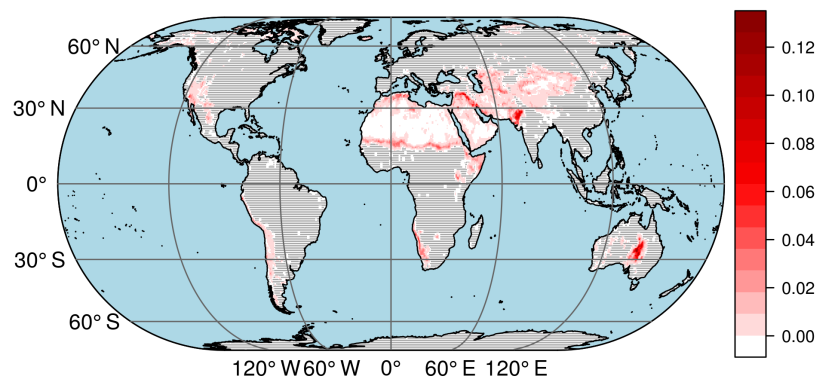

(c)

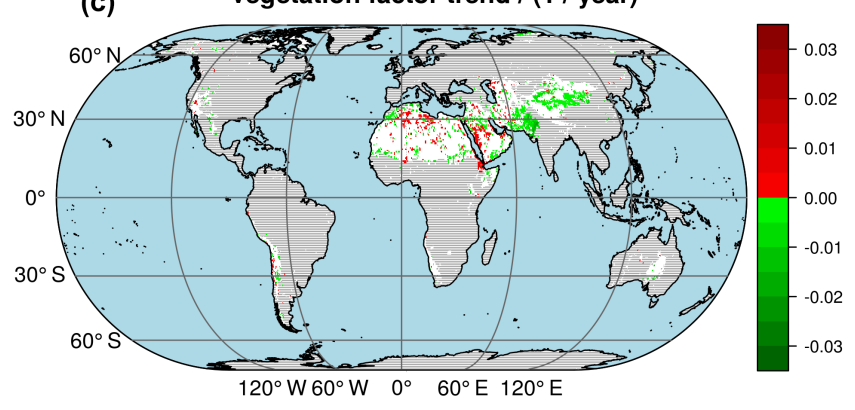

Figure 2. Vegetation factor based on leaf area index data from Yuan et al. (2011) averaged over the period 2000 to 2015 (a), the standard deviation of the annual mean values (b) and the trend of the annual mean values (c). Regions where the land cover mask precludes emissions throughout the period of available land cover data (2001 to 2012) are hatched.

to changing desert boundaries, coincident with the regions of land cover changes, as shown in Fig. 1, can strongly influence the results. The strongest variability is observed in the interior lowlands of Australia (Simpson, Strzelecki and Tirari deserts), the Thar Desert (India/Pakistan) and Mesopotamia. While in Australia the variability does not yield a significant trend over the 16-year period, in and around the Thar Desert a strong decrease of the vegetation factor, indicating vegetation growth, is observed. This inhibits dust emissions and could result in the significant negative AOD trend in that region reported by Klingmüller et al. (2016). In contrast, vegetation decreases in Syria and Iraq, resulting in a larger vegetation factor and more dust emissions. However, similar to Australia, considering the strong variability, the trend is not very distinct because the highest vegetation factor in Iraq and
Syria occurred in 2008 in the middle of the period of available data, whereas it decreased again in recent years.

\subsection{Clay fraction}

The efficiency of the sandblasting process is very sensitive to the clay fraction of the surface soil. Both very small and very large clay fractions are assumed to suppress the sandblasting efficiency. Our parameterisation of this dependency is discussed in Sect. 3. Replacing the $1^{\circ}$ clay fraction map of Scholes and Brown de Colstoun (2011), here we employ higher resolved clay fraction data from the Global Soil Dataset for use in Earth System Models (GSDE) (Shangguan et al., 2014), aggregated from $30^{\prime \prime}$ to $0.1^{\circ}$. The GSDE provides the clay fraction of the topmost $4.5 \mathrm{~cm}$ soil layer, which is most relevant for sandblasting rather than the clay fraction of the topmost $30 \mathrm{~cm}$ in the data of Scholes and Brown de Colstoun (2011). The two data sets are compared in Fig. S1 in the Supplement.

\section{Modifications to the emission scheme}

\subsection{Sandblasting efficiency}

The sandblasting efficiency used by Astitha et al. (2012), based on the studies of Marticorena and Bergametti (1995) and Tegen (2002), increases exponentially with a clay fraction up to $20 \%$, beyond which the sandblasting is negligible; see Fig. 3. The resulting threshold is problematic in regions where the clay fraction is in the range of this discontinuity; for example, in Iraq and Syria, small variations in the clay fraction can drastically alter the sandblasting efficiency between its maximum and essentially zero. Considering that both the clay fraction data and the sandblasting efficiency measurements are associated with uncertainty, we propose to apply a Gaussian filter. Figure 3 shows the efficiency after applying a filter with an interquartile range of $5 \%$, which is used in the validation simulation discussed below. The filter width could be optimised systematically, but in our experience results are robust by smoothing the distinct peak at $20 \%$ clay fraction. Combining the filtered sandblasting efficiency with the updated clay fraction data (Sect. 2.3) yields the global map presented in Fig. 4.

\subsection{Soil moisture term}

The original emission scheme of Astitha et al. (2012) applies a soil-moisture-dependent correction factor to the threshold friction velocity which increases the threshold and thus reduces dust emissions from wet soils. This correction factor has not been active in MESSy versions up to 2.52, and the higher AOD over the Middle East obtained without the factor generally resembles the satellite observations more closely; its impact when evaluated using soil moisture values from the current EMAC bucket model is rather small (see 


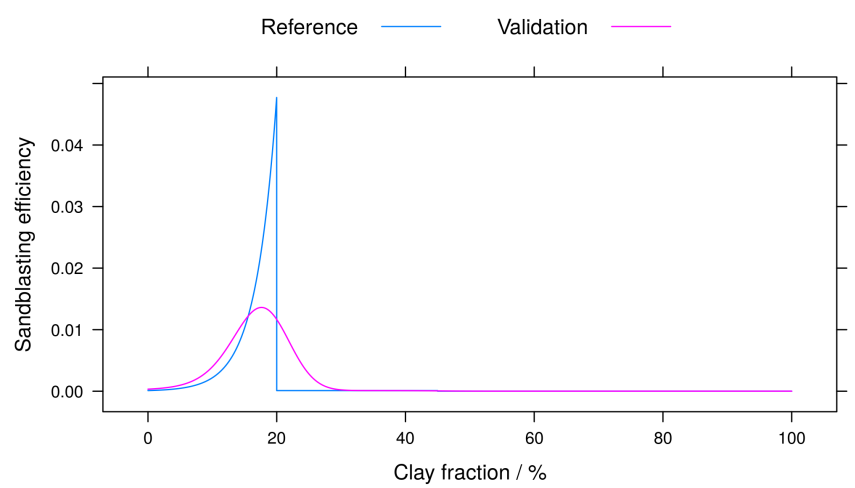

Figure 3. The sandblasting efficiency as function of the clay fraction used by Astitha et al. (2012), before ("reference") and after ("validation") applying a Gaussian filter with an interquartile range of $5 \%$.

Fig. S2 in the Supplement). Therefore, it remains inactive for the present study, consistent with previous studies (Abdelkader et al., 2015; Abdelkader et al., 2016; Metzger et al., 2016; Albani et al., 2014). Nevertheless, the monthly vegetation data described above account for secondary effects of soil moisture variations via the vegetation factor. However, since the soil moisture is known to be a relevant parameter (Gherboudj et al., 2015) and, e.g. strongly correlates with the AOD over the Middle East (Klingmüller et al., 2016), suggesting a direct link between surface drying and increasing dust emissions, we consider a detailed parameterisation of the soil moisture effect to be essential for capturing the observed trends in future simulations. This will require a comprehensive soil model providing accurate moisture values for the topmost surface layer which has yet to be implemented in EMAC.

\subsection{Surface friction velocity limit}

The relation of the horizontal dust particle flux $H$ and the surface friction velocity $u_{*}$ is parameterised as a polynomial of degree 3:

$H \propto \begin{cases}\left(u_{*}+u_{* \mathrm{t}}\right)^{2}\left(u_{*}-u_{* \mathrm{t}}\right) & u_{*}>u_{* \mathrm{t}}, \\ 0 & \end{cases}$

where $u_{* t}$ is the threshold friction velocity. Therefore, high surface friction velocities occurring in mountainous regions can produce spuriously strong dust outbreaks where emissions are not limited by the updated land cover mask, vegetation factor or sandblasting efficiency, e.g. in Iran. To avoid this, we limit the friction velocity in the above equation to a maximum value of $0.4 \mathrm{~m} \mathrm{~s}^{-1}$. Figure S3 in the Supplement exemplifies the effect of using larger or smaller limits. The precise limit might be further adjusted, but the given value yields good results as shown in Sect. 5 .

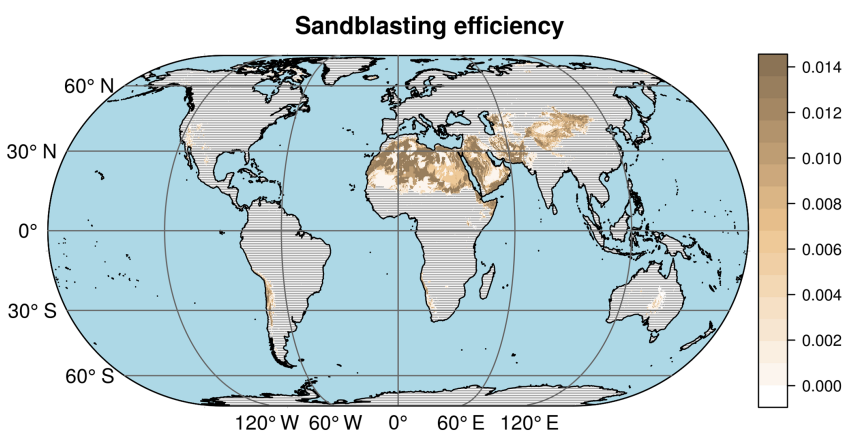

Figure 4. Global map of the sandblasting efficiency obtained by applying the filtered efficiency function shown in Fig. 3 to the GSDE clay fraction data. Regions where the land cover mask precludes emissions throughout the period of available land cover data (2001 to 2012) are hatched.

\subsection{Topography factor}

In the original scheme, the accumulation of sediments in valleys and depressions is not considered explicitly and is only to some extent reflected implicitly by other input data such as the clay fraction. As shown by the reference simulation presented in Sect. 5, this can result in an underestimation of dust emissions from areas like the Tigris-Euphrates Basin. We therefore include a topography factor using the topographic source function proposed by Ginoux et al. (2001):

$S_{\text {topo }}=\left(\frac{z_{\max }-z}{z_{\max }-z_{\min }}\right)^{5}$

where $z$ is the median elevation in a circle with $1^{\circ}$ diameter and $z_{\min }\left(z_{\max }\right)$ the minimum (maximum) elevation in the surrounding circle with $10^{\circ}$ diameter. (Ginoux et al., 2001 use $1^{\circ}$ pixels and the extreme values in the surrounding $10^{\circ} \times 10^{\circ}$ square). The Global Multi-resolution Terrain Elevation Data 2010 (GMTED2010) (Danielson and Gesch, 2011; GMTED2010, 2010) is used as a topography database. Figure 5 depicts a global map of the resulting topography factor. As the topography factor takes values between 0 and 1 , and usually is smaller than 1 , a normalisation factor $N \geq 1$ has to be multiplied to avoid suppression of the global emissions. In a 1-month test simulation, we obtain a ratio between the global emissions without and including the factor $S_{\text {topo }}$ of 5.3. Consequently, the full topography term we use is $N S_{\text {topo }}$ where $N=5.3$.

\subsection{Mode mapping}

The emission scheme considers emissions into three $\log$ normal modes, adapting the parameters of the "background" modes of d'Almeida (1987) listed in Table 2. Originally, these log-normal modes have been mapped to eight transport bins as used by Pérez et al. (2006), before being distributed to the accumulation and coarse mode of the EMAC 
Table 1. Summary of updated and added input data.

\begin{tabular}{|c|c|c|c|}
\hline & & Reference input data & Updated/new input data \\
\hline \multirow[t]{3}{*}{ Land cover } & Source & Olson (1992) & MODIS MCD12C1 (2016) \\
\hline & Spatial resolution & $1^{\circ}$ (aggregated from $\left.10^{\prime}\right)$ & $0.05^{\circ}$ \\
\hline & Temporal resolution & Static & Yearly data (since 2001) \\
\hline \multirow[t]{4}{*}{ Clay fraction } & Source & $\begin{array}{l}\text { Scholes and Brown de Colstoun } \\
\text { (2011) }\end{array}$ & GSDE (Shangguan et al., 2014) \\
\hline & Spatial resolution & $1^{\circ}$ & $0.1^{\circ}$ (aggregated from $30^{\prime \prime}$ ) \\
\hline & Temporal resolution & Static & Static \\
\hline & Notes & Clay fraction in top $30 \mathrm{~cm}$ soil layer & $\begin{array}{l}\text { Clay fraction in top } 4.5 \mathrm{~cm} \text { soil } \\
\text { layer }\end{array}$ \\
\hline \multirow[t]{4}{*}{ Vegetation } & Source & $\begin{array}{l}\text { Kergoat et al. (1999), Bonan et al. } \\
\text { (2002) }\end{array}$ & Yuan et al. (2011) \\
\hline & Spatial resolution & $1^{\circ}$ (aggregated from $0.5^{\circ}$ ) & $0.1^{\circ}$ (aggregated from $30^{\prime \prime}$ ) \\
\hline & Temporal resolution & $\begin{array}{l}\text { Monthly values (April } 1992 \text { to } \\
\text { March 1993) }\end{array}$ & $\begin{array}{l}\text { Monthly values (since } 2000 \text {, aggre- } \\
\text { gated from } 8 \text {-day values) }\end{array}$ \\
\hline & Notes & & MODIS based \\
\hline \multirow[t]{3}{*}{ Topography } & Source & - & $\begin{array}{l}\text { Danielson and Gesch (2011), } \\
\text { GMTED2010 (2010) }\end{array}$ \\
\hline & Spatial resolution & - & $0.1^{\circ}$ (aggregated from $30^{\prime \prime}$ ) \\
\hline & Temporal resolution & - & Static \\
\hline \multirow[t]{3}{*}{ Chemical composition } & Source & - & $\begin{array}{l}\text { Karydis et al. (2016), Natural Earth } \\
\text { (2016) }\end{array}$ \\
\hline & Spatial resolution & - & $0.1^{\circ}$ \\
\hline & Temporal resolution & - & Static \\
\hline
\end{tabular}

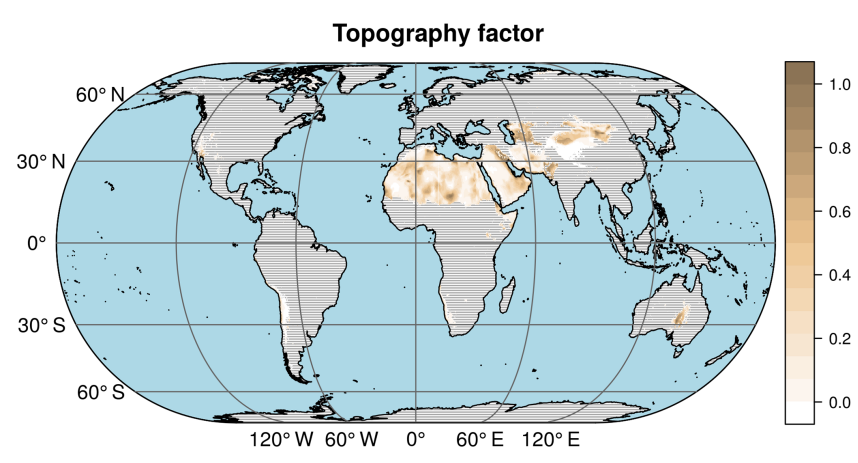

Figure 5. The topography factor defined by Eq. (3), calculated using the GMTED2010 elevation data. Regions where the land cover mask precludes emissions throughout the period of available land cover data (2001 to 2012) are hatched.

aerosol Global Modal-aerosol eXtension (GMXe) submodel. We simplify this procedure by directly mapping the three emission modes to the two relevant GMXe modes. The mass fraction $M$ assigned to each GMXe mode is

$$
M=\sum_{i=1}^{3} \frac{1}{2}\left(\operatorname{erf}\left(\frac{\ln \left(d_{\max } / \tilde{d}_{i}\right)}{\sqrt{2} \ln \sigma_{\mathrm{g}, i}}\right)-\operatorname{erf}\left(\frac{\ln \left(d_{\min } / \tilde{d}_{i}\right)}{\sqrt{2} \ln \sigma_{\mathrm{g}, i}}\right)\right)
$$

where the sum encompasses the three emission modes, $\widetilde{d}_{i}$ and $\sigma_{\mathrm{g}, i}$ are the mass median diameter and geometric standard deviation of each emission mode, and $d_{\min }$ and $d_{\max }$ are the threshold diameters of the GMXe mode. In practice, the modification is equivalent to a change of the threshold diameter between the accumulation and coarse modes, which is now consistent with the GMXe parameters. Moreover, the algorithm generalises seamlessly when including additional GMXe modes such as a giant aerosol mode $(>10 \mu \mathrm{m})$.

\subsection{Scaling factor}

For the dimensionless empirical constant $c$ by which the horizontal particle flux is scaled, Astitha et al. (2012) use the value $c=1$, consistent with Darmenova et al. (2009). Since the dust emissions, especially in the Middle East, tend to underestimate the observations, we increase the value to $c=1.5$, which is bounded by the original value and $c=$ 2.61 used by White (1979) and Marticorena and Bergametti (1995). When switching to different model resolutions, the scaling factor can be used to balance potential resolution dependencies of the emission scheme. As will be discussed in Sect. 5, with this value, we obtain the same total amount of globally emitted dust as with the original emission scheme by Astitha et al. (2012). It should be stressed that the scaling factor is the central empirical tuning parameter of the emis- 
sion scheme and might be improved by systematic optimisation, but our focus is on the spatiotemporal emission pattern which is largely unaffected by the overall scaling.

\subsection{Chemical composition}

In addition to the bulk dust flux output, we compute the $\mathrm{Na}^{+}$, $\mathrm{K}^{+}, \mathrm{Ca}^{++}$and $\mathrm{Mg}^{++}$fractions of the emitted dust, since mineral cations are important for the gas-aerosol partitioning (Metzger et al., 2006). For this purpose, we have generated maps of the desert soil composition (Fig. 6) based on the fractions reported by Karydis et al. (2016) and geographical data from the Natural Earth data set (Natural Earth, 2016). The chemical composition does not affect the amount of dust emitted, but the chemical ageing of airborne dust particles simulated by the GMXe submodel can affect the atmospheric residence time (Abdelkader et al., 2015) and the optical properties (Klingmüller et al., 2014).

\section{Effects of the individual modifications}

To compare the effects of the individual modifications, we study the term $a \cdot f_{\text {landcover }} \cdot f_{\text {veg }} \cdot N S_{\text {topo }}$ (compare Eq. A2 in the Appendix): the product of the clay-fractiondependent sandblasting efficiency $(a)$, the barren land fraction $\left(f_{\text {landcover }}\right)$, the vegetation factor $\left(f_{\text {veg }}\right)$ and the normalised topography factor ( $\left.N S_{\text {topo }}\right)$. This term is proportional to the dust emission flux (given that the threshold surface friction velocity is exceeded) and reflects the effects of the modifications independently of the precise wind conditions. Figure 7 compares the term during July 2011 for the reference and validation simulation, and variations of the validation setup selectively using either the land cover, sandblasting efficiency, clay fraction or vegetation data from the reference scheme, or omitting the topography factor. The update of the land cover data, the inclusion of the topography factor and the modification to the sandblasting efficiency distinctively affect the dust emissions, whereas the update of clay fraction and vegetation data has a more subtle effect (see also Fig. S4 in the Supplement). The latter implies that the effect of the seasonal cycle in the vegetation data is not clearly visible in this representation, justifying to study only July in Fig. 7. The land cover update clearly expands the source regions of the dust belt. The topography factor redistributes the emissions, enhancing emissions from basins (e.g. the Tigris-Euphrates Basin) while reducing emissions from mountainous areas. Omitting the topography factor, the revised scheme produces a much more homogeneous distribution. The revised sandblasting efficiency avoids pixels with very strong or very little emissions in regions with a clay fraction of around $20 \%$. In such regions, reverting to the original sandblasting efficiency yields peaks of extremely high emission factors, defining the upper limit of the colour scale in Fig. 7. This is especially the case in regions where the original scheme suppressed emissions based on the land cover classification; therefore, the revised sandblasting efficiency is mandatory when using the updated land cover data. Most importantly, to the benefit of future high-resolution simulations with truncations of T255 or higher $(<50 \mathrm{~km}$ grid spacing), the updates considerably increase the resolution of the emission factor as illustrated by the column on the righthand side of Fig. 7.

\section{Validation}

We use EMAC in the combination ECHAM 5.3.02 and MESSy 2.52 at horizontal resolution T106 with 31 vertical levels. The Gaussian T106 grid has a grid spacing of $1.125^{\circ}$ along the latitudes and about $1.121^{\circ}$ along the longitudes. At the Equator, this corresponds to virtually quadratical cells with around $125 \mathrm{~km}$ edge length. The following MESSy submodels have been enabled: AEROPT, AIRSEA, CLOUD, CLOUDOPT, CONVECT, CVTRANS, DDEP, GMXe, JVAL, LNOX, MECCA, OFFEMIS, ONEMIS, ORBIT, ORACLE, PTRAC, RAD, SCAV, SEDI, SURFACE, TNUDGE and TROPOP. Descriptions of each submodel and further references can be found online in the MESSy submodel list (MESSy 2017, 2017). The dust emission scheme is evaluated by the online emission submodel ONEMIS; the aerosol microphysical processes are simulated by the GMXe submodel (Pringle et al., 2010a, b). Within GMXe, two gasaerosol partitioning schemes are available: ISORROPIA II (Fountoukis and Nenes, 2007) and EQSAM4clim (Metzger et al., 2016); here, we employ the former. The prognostic radiative-transfer calculation uses the Tanre aerosol climatology for extinction, single scattering albedo and asymmetry factor (Tanre et al., 1984), and the model dynamics above the boundary layer are nudged to meteorological analyses of the European Centre for Medium-Range Weather Forecasts (ECMWF). The fifth phase of the Coupled Model Intercomparison Project (CMIP5), Global Fire Emissions Database (GFED) v3.1 and Aerosol Comparisons between Observations and Models (AeroCom) databases provide anthropogenic, biomass burning and sea salt emissions, respectively.

Two simulations are considered: a reference simulation using the original emission scheme and a validation simulation using the updated input data presented in Sect. 2 and the modifications presented in Sect. 3. The different input data sets are summarised in Table 1. The chemical composition of the emitted particles is considered in both simulations. As a validation time period, we selected the year 2011 to represent a recent period well past the time period on which the former input data were based on. The simulations are initialised on 1 July 2010 from the output of a lower resolving T42 simulation starting in 1998. After this initialisation, 6 months simulated with the final T106 resolution serve as additional spin-up period. 

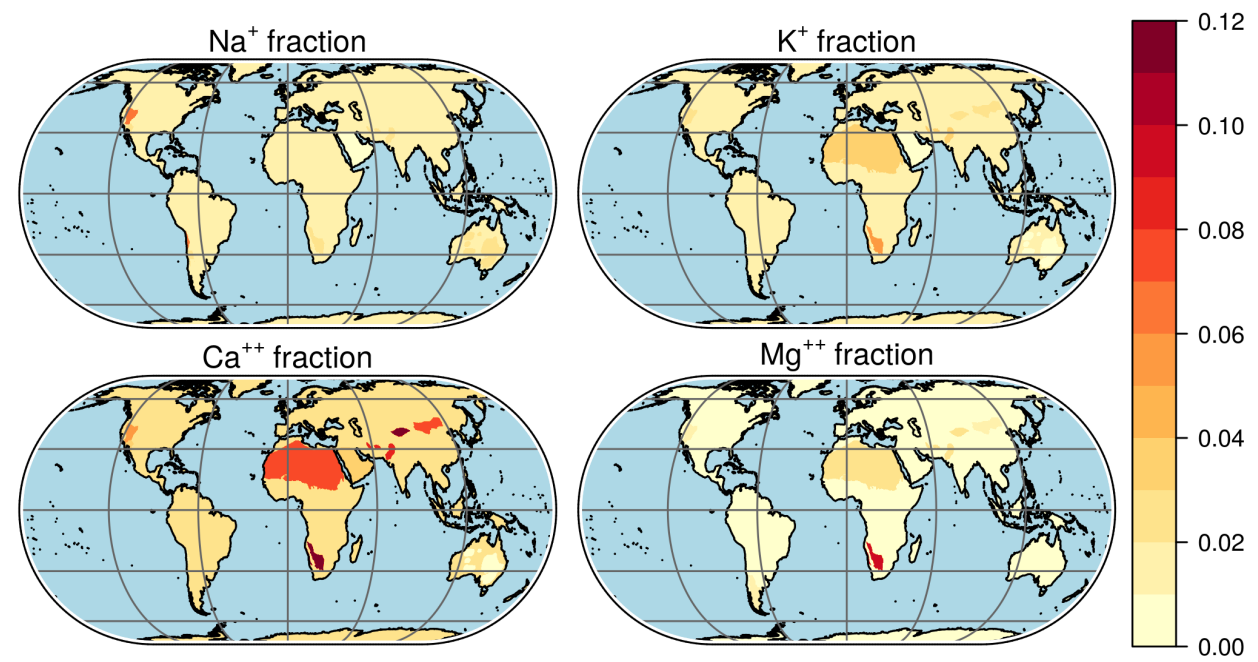

Figure 6. Maps of the $\mathrm{Na}^{+}, \mathrm{K}^{+}, \mathrm{Ca}^{++}$and $\mathrm{Mg}^{++}$mass fractions of the soil of different desert regions, used to calculate the chemical composition of the emitted dust particles.

Table 2. Parameters of emission and GMXe dust modes. The GMXe parameter values shown have been used for reference and validation simulations.

\begin{tabular}{lrrrr}
\hline & $\sigma_{g}$ & $\tilde{d} / \mu \mathrm{m}$ & $d_{\min } / \mu \mathrm{m}$ & $d_{\max } / \mu \mathrm{m}$ \\
\hline Emission modes & 2.1 & 0.83 & & \\
& 1.9 & 4.82 & & \\
& 1.6 & 19.4 & & \\
\hline GMXe dust modes & 1.59 & & 0.12 & 2 \\
& 2 & & 2 & $\infty$ \\
\hline
\end{tabular}

To quantify the (dis)agreement of model results and observations, we use the skill score $S$ defined by Taylor (2001):

$S=\frac{4(1+r)^{4}}{\left(\sigma_{1} / \sigma_{2}+\sigma_{2} / \sigma_{1}\right)^{2}\left(1+r_{0}\right)^{4}}$,

where $r$ is the correlation coefficient, and $\sigma_{1}$ and $\sigma_{2}$ are the standard deviations of modelled and observed values. As a maximum attainable correlation coefficient, we simply use $r_{0}=1$, since we are predominantly interested in the relative changes of the skill score resulting from our modifications to the dust emission scheme. A more accurate estimate of $r_{0}<1$ would result in higher skill scores.

Both simulations obtain the same global mineral dust emission of $1.3 \mathrm{Gt}$ in 2011 (Table 3), which is well in the range of values reported by Huneeus et al. (2011) and close to their median of $1.1 \mathrm{Gt}$ per year. Aligning the threshold between accumulation and coarse modes with GMXe as described in Sect. 3 for the parameters shown in Table 2 results in more accumulation-mode emissions in the validation simulation $\left(0.15 \mathrm{Gt} \mathrm{yr}^{-1}\right)$ than in the reference simulation $\left(0.052 \mathrm{Gt} \mathrm{yr}^{-1}\right)$; thus, higher $550 \mathrm{~nm}$ AOD values are expected in the former.
Table 3. Global mineral dust emissions in 2011 obtained by EMAC.

\begin{tabular}{lll}
\hline & Validation simulation & Reference simulation \\
\hline Accumulation mode & $0.148 \mathrm{Gt} \mathrm{yr}^{-1}$ & $0.0517 \mathrm{Gt} \mathrm{yr}^{-1}$ \\
Coarse mode & $1.16 \mathrm{Gt} \mathrm{yr}^{-1}$ & $1.28 \mathrm{Gt} \mathrm{yr}^{-1}$ \\
Total & $1.31 \mathrm{Gt} \mathrm{yr}^{-1}$ & $1.33 \mathrm{Gt} \mathrm{yr}^{-1}$ \\
\hline
\end{tabular}

\subsection{AERONET}

For the comparison with Aerosol Robotic Network (AERONET) (Holben et al., 1998; AERONET, 2016) AOD observations, we select regions based on the relevance of the regional dust emissions and the abundance of AERONET stations. We focus on the seven regions of interest depicted in Fig. 8, encompassing the Middle East (ME), north-west Africa (N. Afr.), Africa, central and east Asia (Asia), the south-west of the United States of America (N. Amer.), the southern cone in South America (S. A.) and Australia (Austral.). All stations with observations for at least 120 days distributed over at least 9 months of 2011 are considered.

We compare daily averages of modelled and observed AOD at $550 \mathrm{~nm}$, where the AERONET AOD at this wavelength is obtained from level-2 data by interpolation using the Ångström exponent. For each station, we use the model values from the grid cell covering the station coordinates. The skill score $S$ is shown in Fig. 9. For most stations, the validation simulation achieves higher skill scores than the reference simulation (time series plots for the stations with the highest increase are shown in Fig. S5 in the Supplement); similar skill scores are obtained for the Australian stations. Only over four stations in north-west Africa does the validation simulation produce noticeably lower skill scores than the reference run. However, the skill scores for these stations re- 

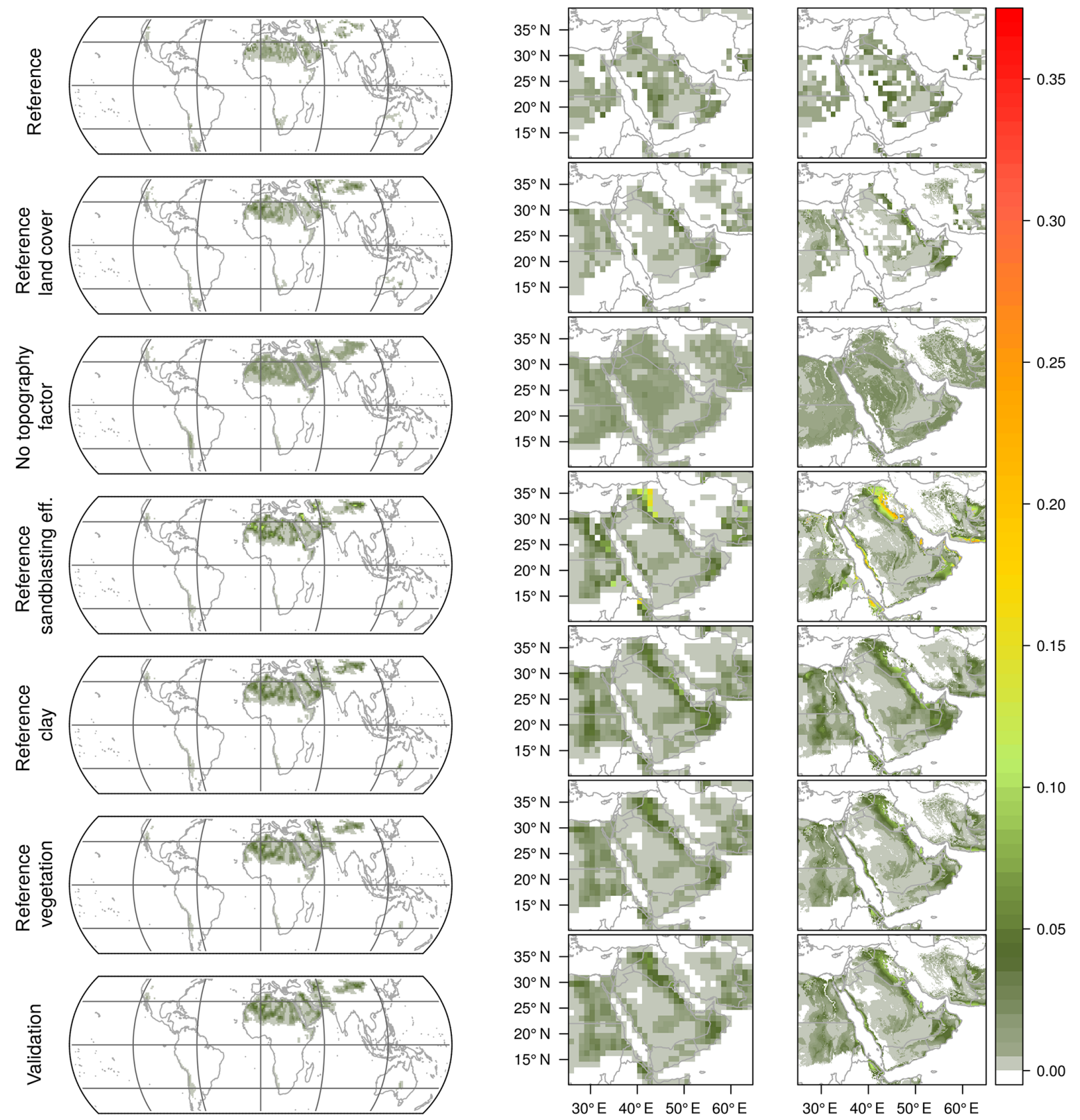

Figure 7. Distribution of the emission factor $a \cdot f_{\text {landcover }} \cdot f_{\mathrm{veg}} \cdot N S_{\text {topo }}$ during July 2011 for (from top to bottom) the original emission scheme, the revised emission scheme but using the reference land cover data, no topography factor, the reference sandblasting efficiency, clay fraction or vegetation, and the revised emissions. For the first and second columns from the left, all data have been regridded to T106 resolution; the third column showing the Middle East illustrates the effect of using the full resolution of the revised input data.

main among the highest globally. Moreover, the two stations with the strongest skill score degradation are located very close to each other on the island Tenerife, in Santa Cruz de Tenerife and at the Izaña Atmospheric Observatory on Mount Teide. In contrast, the validation skill score for a third station on Tenerife, in La Laguna, is marginally larger than the corresponding reference skill score.

Studying the AOD time series for these three stations (Fig. 10a) reveals that over Santa Cruz de Tenerife the model slightly overestimates the observations and the even higher AOD levels in the validation simulation result in the lower skill score. On the other hand, dust events observed by AERONET in January and December are reproduced by the validation simulation but not by the reference simulation. The Izaña station on Mount Teide is special: located at $2391 \mathrm{~m}$ altitude, it shares the same model grid cell with the La Laguna station at $568 \mathrm{~m}$ altitude, Fig. 10b, but naturally the observed AOD is much lower. Obviously, the station site 


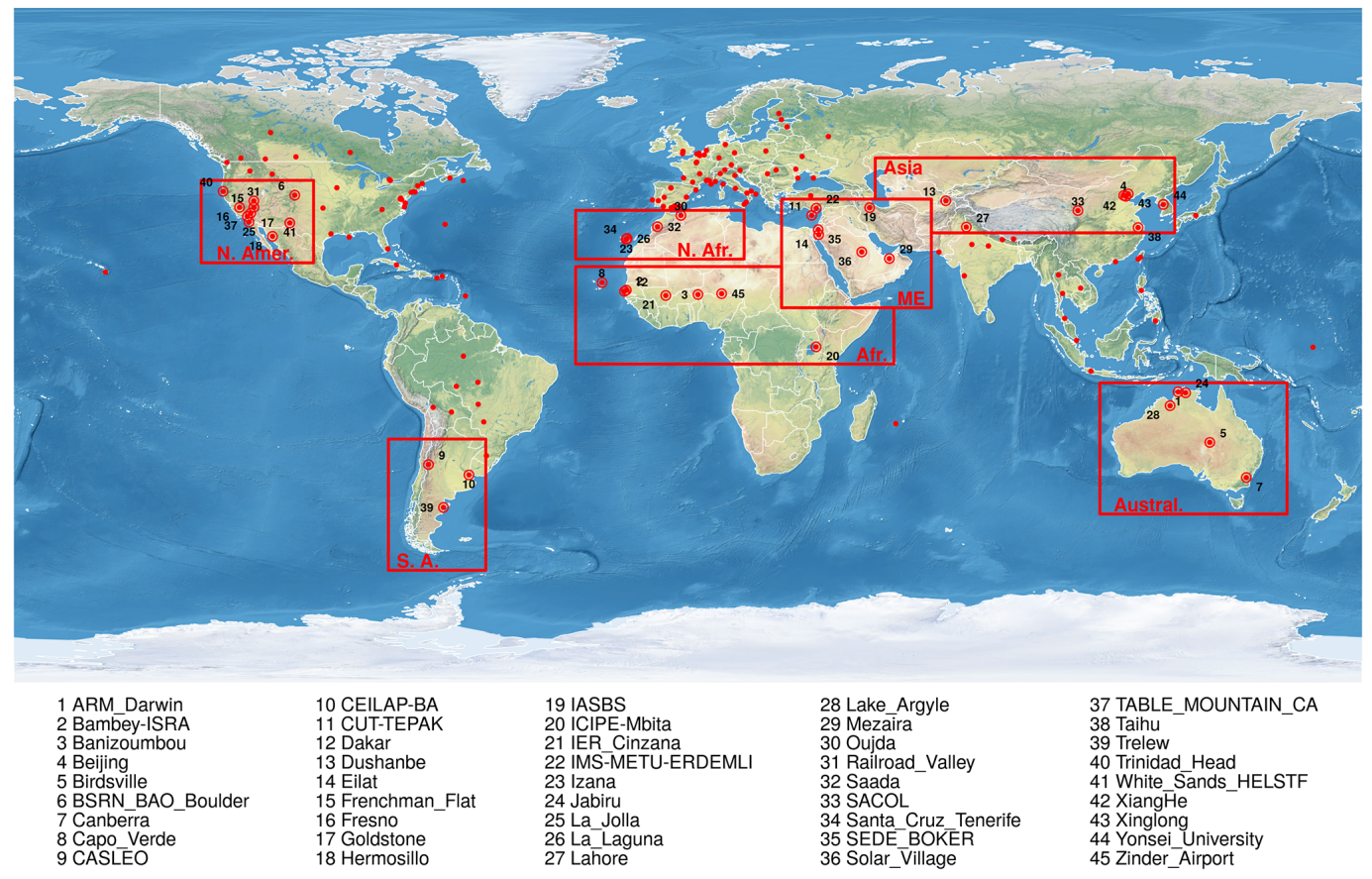

Figure 8. AERONET stations and regions of interest used for the evaluation. Stations with data for 120 or more days distributed over at least 9 months of 2011 (red dots) are considered, yielding 45 stations within the regions of interest (labelled).

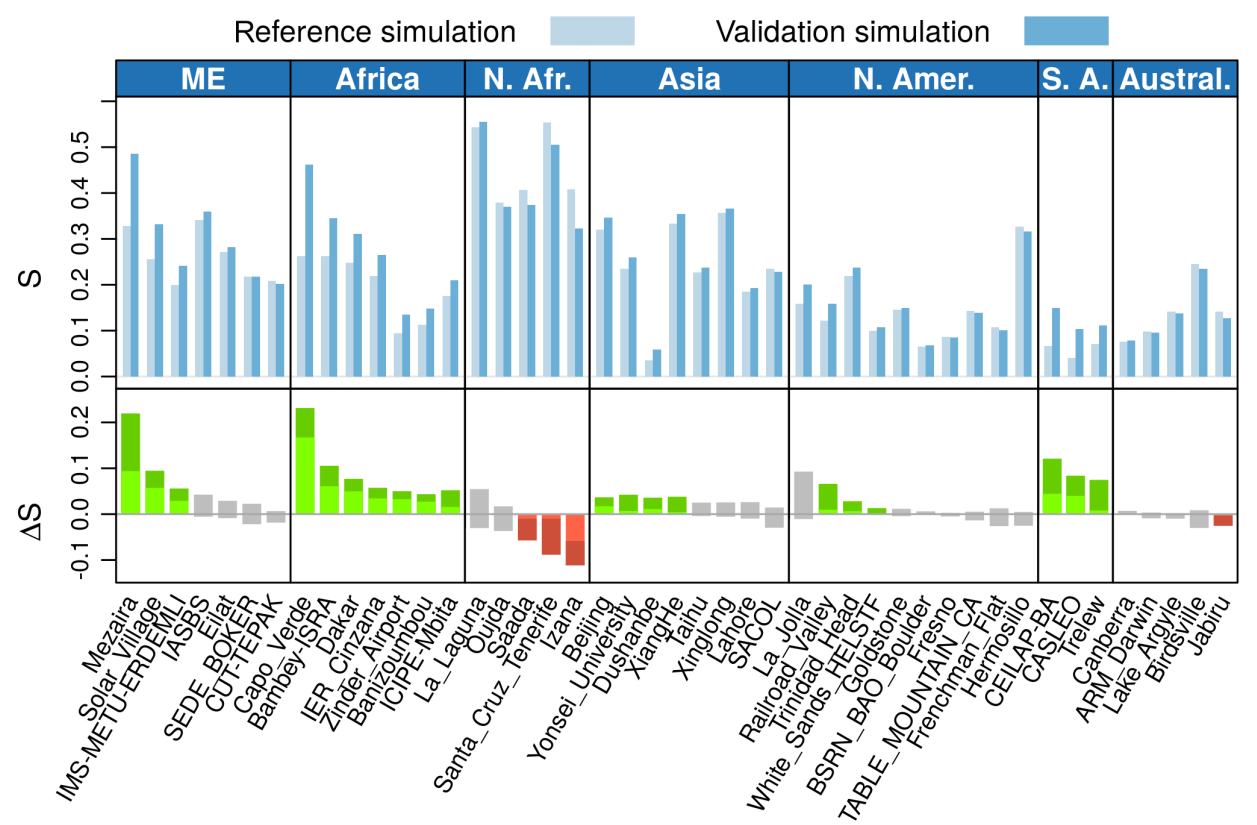

Figure 9. Skill score $(S)$ of the daily mean $550 \mathrm{~nm}$ AOD from reference and validation simulations using AERONET observations as a benchmark. The red, green and grey bars depict the differences between reference and validation values, with green bars indicating that the validation results agree more closely with the measurements by at least 1 standard deviation $(\sigma)$. The corresponding error intervals are indicated by darker colours. Generally, the validation simulation performs better than the reference simulation; regarding the decreased skill scores in north-west Africa, please refer to the discussion in the main text. 


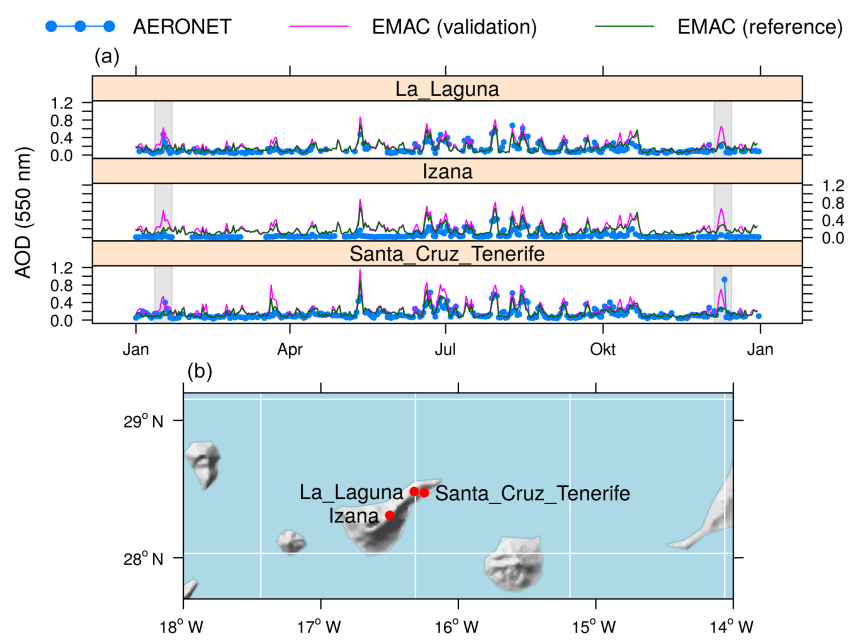

Figure 10. Time series of the daily mean AOD at the Canarian AERONET stations (a) and a map showing the location of the stations (b). The white squares depict the T106 model grid. During the grey-shaded periods of the time series in January and December, at least one of the three AERONET stations observed an AOD peak which is reproduced by the validation but not by the reference simulation.

is not well represented by the model grid cell, which predominantly covers open sea and has a surface altitude of $63 \mathrm{~m}$. These considerations put the regression of the skill score over the Canaries into perspective and suggest that some overestimation of the AOD over north-west Africa in the validation simulation is an acceptable trade-off in view of the skill score increase elsewhere. This conclusion is further supported by the comparison with MODIS observations in the following section.

\subsection{MODIS}

To verify the global aerosol distribution, we validate the model AOD against observations from the Terra satellite provided by MODIS Collection 6 (Hubanks et al., 2015; Levy et al., 2013; MODIS MOD08 M3, 2017). We use the merged $550 \mathrm{~nm}$ AOD combining retrievals from the Deep Blue and Dark Target algorithms (Sayer et al., 2014).

Figure 11 compares the 2011 annual mean AOD from the two simulations and MODIS. The AOD levels over the Sahara and the Middle East produced by the validation simulation agree well with the observed levels, whereas they are underestimated by the reference simulation. Features of the MODIS distribution found in the validation but not in the reference result are regionally high AOD values over the Middle East along the gulf and extending over Iraq and Syria, and the absence of a local maximum over Argentina. The latter is even more evident at higher wavelengths considered in the following section. Over west Africa, the high AOD levels in the validation simulation extend slightly further north than observed by MODIS. This is consistent with the overes-

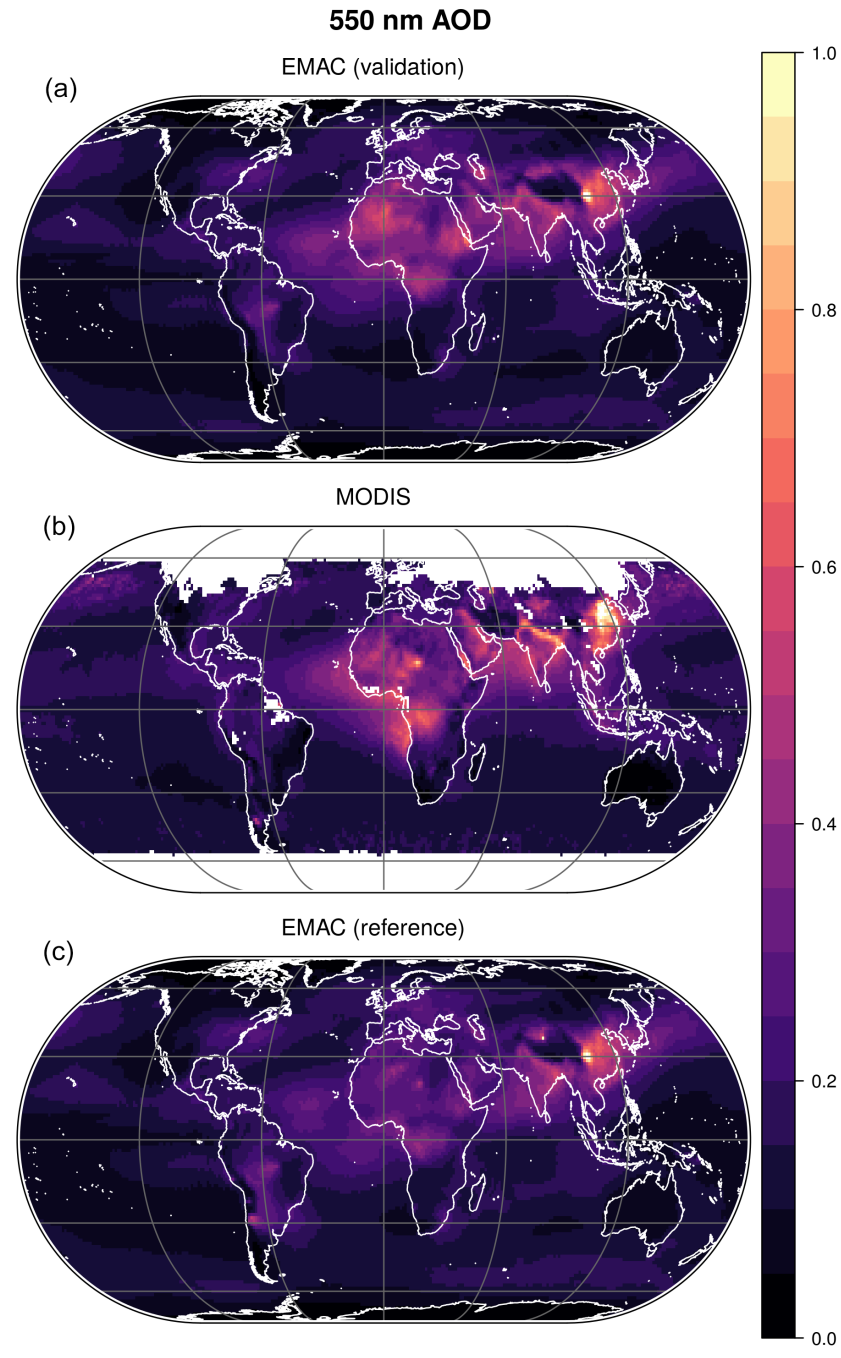

Figure 11. Annual mean for 2011 of the AOD at $550 \mathrm{~nm}$ wavelength observed by MODIS (b) and simulated by EMAC with ("validation", a) and without ("reference", c) revision of the dust emission scheme. The revised dust emissions enhance the correlation of the AOD pattern from 0.79 to 0.81 and the skill score from 0.58 to 0.67 .

timation of AERONET observations in that region discussed above but does not considerably compromise the globally improved agreement with MODIS.

The improved agreement of the AOD distribution obtained by the validation simulation can be quantified by correlating the pixel values of the equivalent maps shown in Fig. 11. The revised dust emissions enhance the spatial correlation of the AOD pattern from 0.79 to 0.81 and the skill score from 0.58 to 0.67 .

Figure 12 zooms into the Middle East to illustrate the annual variability of the $550 \mathrm{~nm}$ AOD by showing seasonal means. Especially in spring and summer, the enhanced AOD levels along the Tigris-Euphrates Basin and the gulf are clearly visible in the validation result, consistent with the 


\section{$550 \mathrm{~nm}$ AOD}
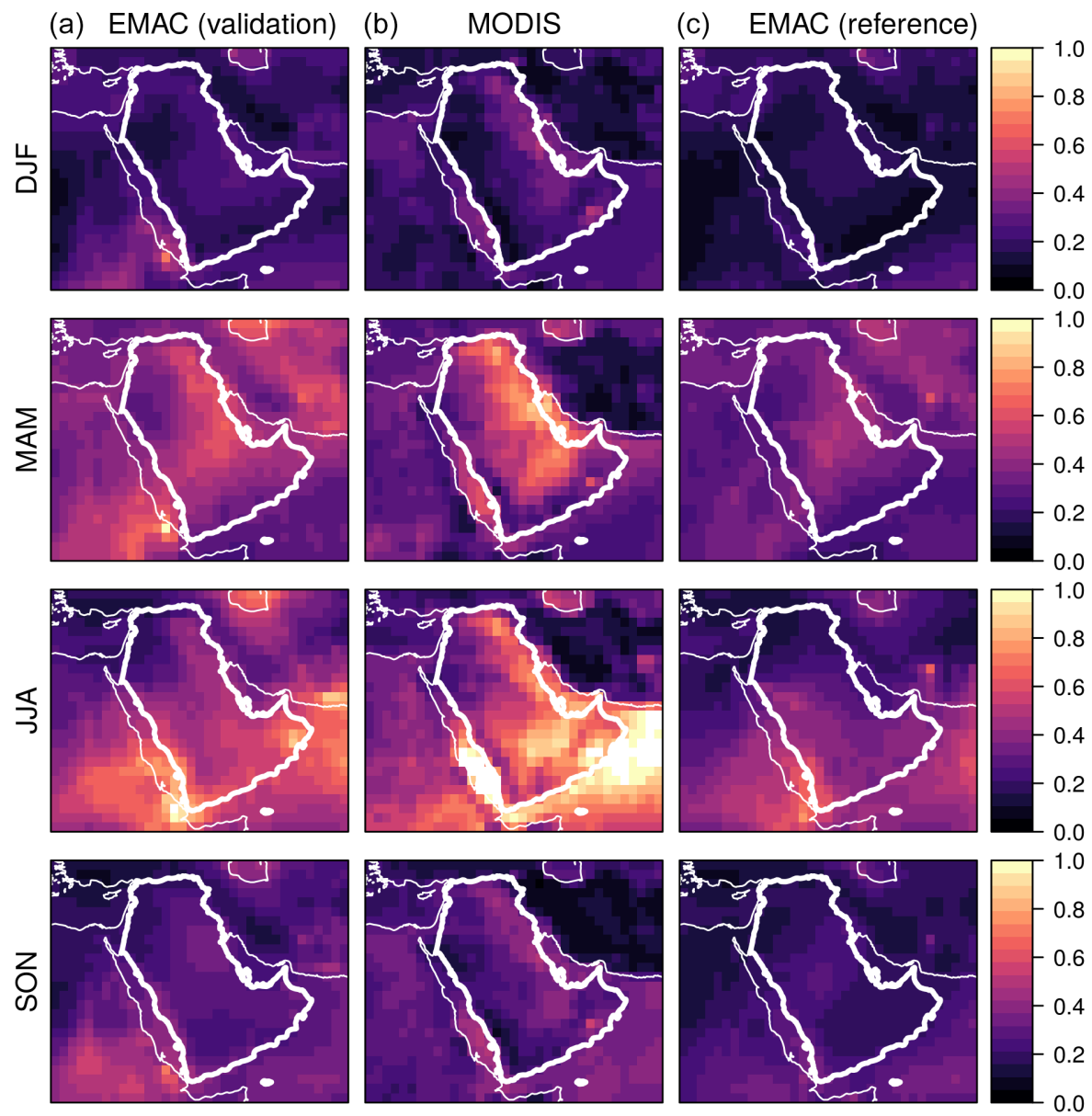

Figure 12. Seasonal $550 \mathrm{~nm}$ AOD over the Middle East in 2011 observed by MODIS (b) and simulated by EMAC with ("validation", a) and without ("reference", c) revision of the dust emission scheme. Each row shows the 3-month averages over the periods (from top to bottom) DJF (December, January, February), MAM (March, April, May), JJA (June, July, August) and SON (September, October, November). Especially throughout the white-bounded region encompassing the Arabian Peninsula including Iraq, Syria and Jordan, the AOD distribution obtained with the revised dust emissions agrees significantly better with the MODIS observations (see Fig. S6 in the Supplement).

MODIS observations, while not being represented in the reference results. During summer, the validation simulation produces higher AOD levels also over Arabian and Red Sea, which are closer to the extremely high levels reported by MODIS and Brindley et al. (2015). Surprisingly, the MODIS AOD over Iran is close to zero throughout the year, but substantial levels are obtained during spring and summer by both simulations, with higher levels in the validation simulation than in the reference simulation. The strong seasonal cycle over the Middle East observed by MODIS is reproduced by both simulations, but with its higher spring and summer AOD levels, the validation simulation yields a higher amplitude in better agreement with MODIS. To underscore the improvement achieved by the revised emissions, we quantify the spatial agreement of the seasonal AOD over the Arabian Peninsula including Syria, Iraq and Jordan using the correlation coefficient and the skill score (see Fig. S6 in the Supplement). Both measures show a significant increase throughout the year, especially during winter (the correlation coefficient from 0.18 to 0.54 ; the skill score from 0.068 to 0.24 ) and summer (the correlation coefficient from 0.46 to 0.75 ; the skill score from 0.22 to 0.55 ). The global seasonal AOD distribution is shown in Figs. S8 to S11 in the Supplement.

\subsection{IASI}

To focus the evaluation more tightly on dust, we utilise data from the Infrared Atmospheric Sounding Interferometer (IASI) (Clerbaux et al., 2009; Hilton et al., 2012) provided by the Aerosol_cci (Climate Change Initiative) project (Popp et al., 2016; IASI, 2016) of the European Space Agency (ESA). We use version 7 of the level-3 monthly dust 


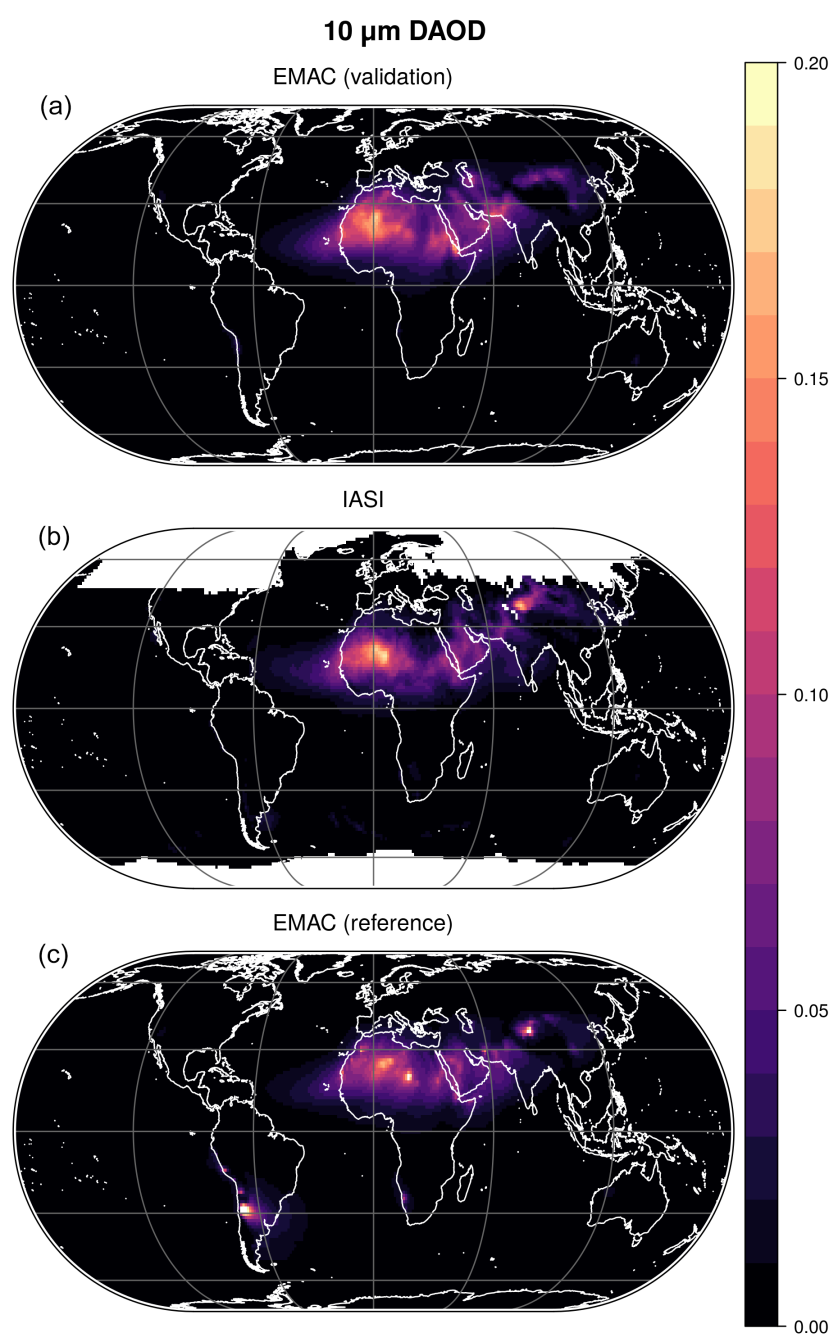

Figure 13. Annual mean for 2011 of the DAOD at $10 \mu \mathrm{m}$ wavelength observed by IASI (b) and simulated by EMAC with ("validation", a) and without ("reference", c) revision of the dust emission scheme. The revised dust emissions enhance the correlation of the AOD pattern from 0.79 to 0.89 and the skill score from 0.64 to 0.78 .

AOD (DAOD) at $10 \mu \mathrm{m}$ prepared at the Université Libre de Bruxelles (IASI_ULB.v7). The corresponding annual average DAOD map for 2011 is shown in Fig. 13b.

To compare with the IASI DAOD, we filter the daily $10 \mu \mathrm{m}$ EMAC AOD considering only dust-dominated values as DAOD, setting the DAOD to zero if sea salt dominates instead. The contribution of both components is quantified by weighting the AOD of each mode with the volume fraction of the component. The diagnostic output of optical properties at wavelengths up to $10 \mu \mathrm{m}$ has not been utilised previously in EMAC, though proves very valuable to compare with remotely sensed optical properties of coarse particles such as aeolian dust. The annual averages for 2011 from validation and reference simulations are shown in Fig. 13a and c. In several aspects, the DAOD distribution obtained by the validation simulation resembles the IASI observations more closely. In the Middle East, the region of high dust loads distinctly extends north-westwards into the Fertile Crescent, whereas comparably low dust loads are found over the western half of the Arabian Peninsula. The DAOD is more pronounced over Pakistan, and similarly over Djibouti and the adjacent regions south-west of the Red Sea. The regional maximum over Chad is less distinct than in the reference simulation. Over the Southern Andes, the maximum obtained by the reference simulation, though not detected by IASI, is not reproduced by the validation simulation, which is distinctly more realistic.

The correlation coefficient of the validation result and IASI is 0.89 compared to 0.79 for the reference simulation; the corresponding skill score is enhanced by our modifications from 0.64 to 0.78 .

The annual variability of the $10 \mu \mathrm{m}$ DAOD over the Middle East is compared in Fig. 14. As for the AOD, in spring and summer, the high DAOD values along the Tigris-Euphrates Basin are clearly visible in the validation result, consistent with the IASI observations, while not being represented in the reference result. During summer, the DAOD pattern obtained by the validation simulation at the southern Red Sea resembles the pattern observed by IASI, even though the observed regional maximum is more pronounced. Also the DAOD at the Iranian and Pakistani Arabian Sea coast produced by the validation simulation agrees more closely with the IASI result. The reference simulation does not produce dust over the Caspian Sea and to its south, whereas IASI obtains significant DAOD values in spring and summer. These are reproduced by the validation simulation but seem to be slightly overestimated during summer. The strong seasonal cycle observed by IASI is realistically reproduced by both simulations. We quantify the apparent improvement achieved by the revised emissions by assessing the spatial agreement of the seasonal AOD over the Arabian Peninsula (including Syria, Iraq and Jordan) using the correlation coefficient and the skill score (see Fig. S7 in the Supplement). The increase obtained for both measures throughout the year is significant for most seasons, especially during autumn for which the correlation coefficient increases from 0.30 to 0.62 and the skill score from 0.14 to 0.39 . The global seasonal DAOD distribution is shown in Figs. S12 to S15 in the Supplement.

\subsection{Dust concentration and deposition}

We use dust concentration and deposition data from the AeroCom dust benchmark data set (Huneeus et al., 2011) to evaluate the corresponding results of our simulations. Concentration climatologies from 25 sites with a total of 292 monthly values and the annual dust deposition rates from 84 sites are considered for our evaluation (see Fig. S16 in the Supplement). 


\section{0 nm DAOD}
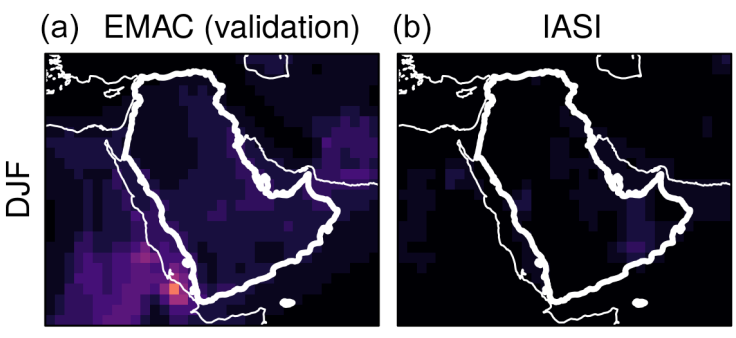

(c) EMAC (reference)
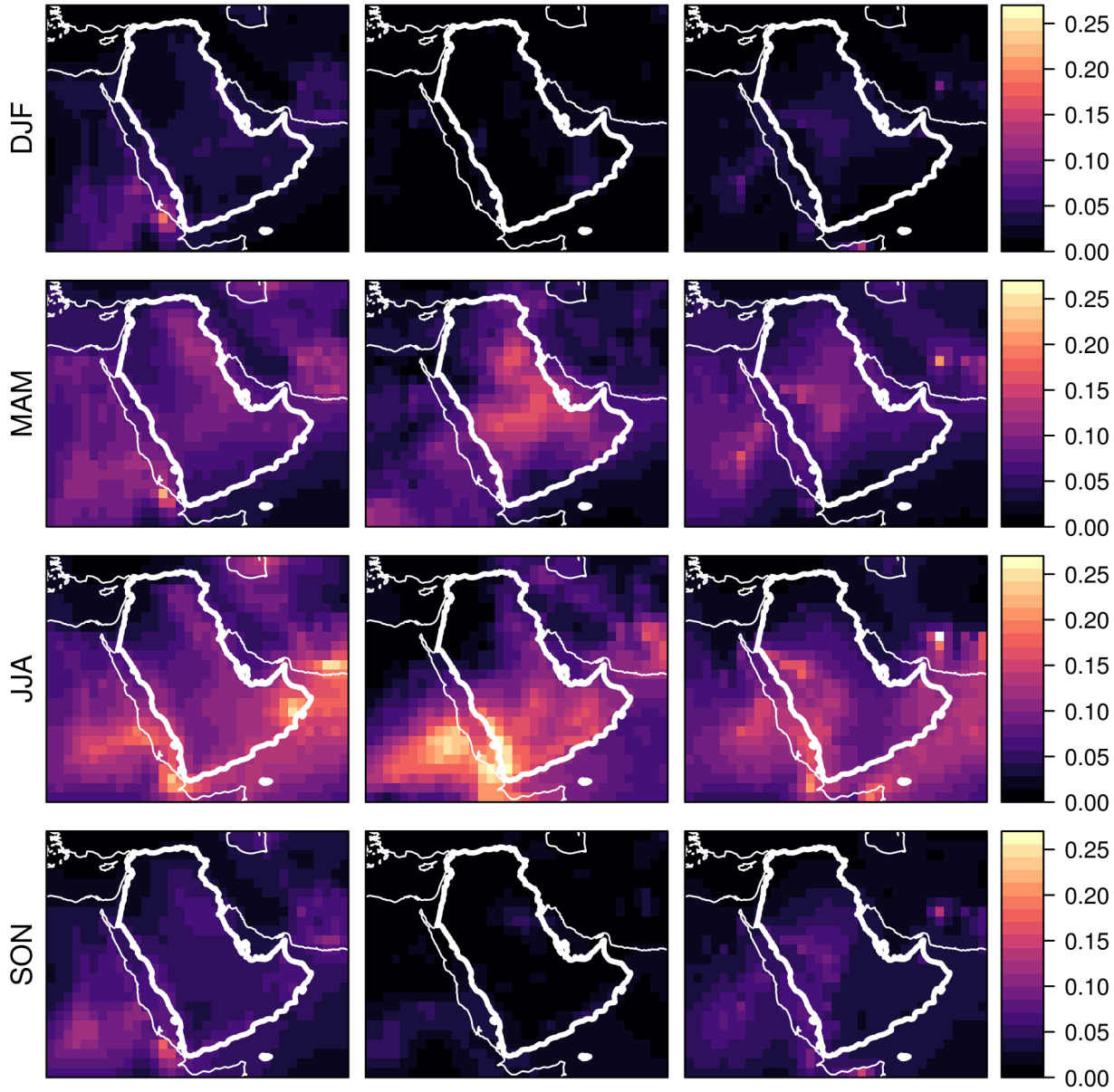

Figure 14. Seasonal $10 \mu \mathrm{m}$ DAOD over the Middle East in 2011 observed by IASI (b) and simulated by EMAC with ("validation", a) and without ("reference", c) revision of the dust emission scheme. Each row shows the 3-month averages over the periods (from top to bottom) DJF (December, January, February), MAM (March, April, May), JJA (June, July, August) and SON (September, October, November). Especially throughout the white-bounded region encompassing the Arabian Peninsula including Iraq, Syria and Jordan, the DAOD distribution obtained with the revised dust emissions agrees significantly better with the IASI observations (see Fig. S7 in the Supplement).

The deposition obtained by the validation simulation agrees significantly better with the observations than the reference result (Fig. 15), with a correlation coefficient of 0.89 compared to 0.80 and a skill score of 0.78 compared to 0.64 . Regarding the concentration, the two simulations show no significant difference in performance.

At sites with low dust concentrations, both simulations underestimate the observed concentrations which could be either due to an underestimation of dust transport in the model or due to local non-desert dust sources not represented in the dust emission schemes.

\section{Conclusions}

We have prepared new input data for use with the EMAC dust emission scheme developed by Astitha et al. (2012), and proposed changes and extensions. With a geographic representation of at least $0.1^{\circ}$ for all input parameters, the updated input data have a significantly higher spatial resolution than the data used thus far. Therefore, the new data will be important for use in planned high-resolution simulations with truncations of T255 or higher $(<50 \mathrm{~km})$. The land cover and vegetation in the updated data are time dependent, so that the effect of long-term trends and variability of these quantities on the dust emissions are taken into account. In addition to the input parameters used by the original implementation by Astitha et al. (2012), we take the topography into ac- 

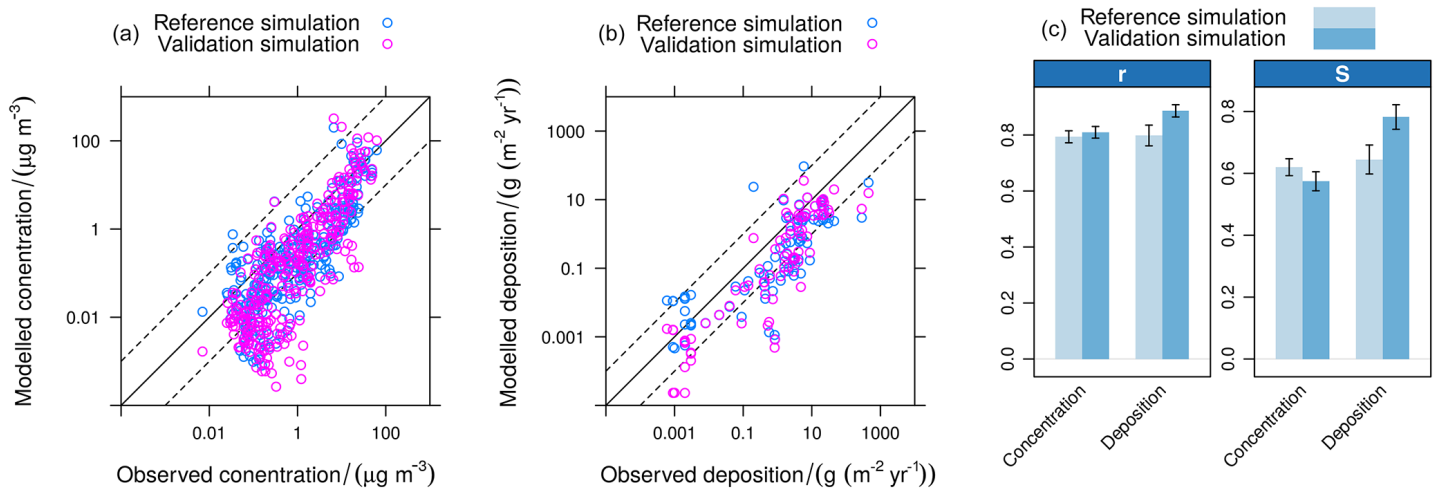

Figure 15. Comparison of modelled and observed dust concentration and deposition: scatterplots of monthly concentrations (a) and annual deposition (b), and bar charts of the corresponding correlation coefficients $r$ and skill scores $S$ (c). The observations are taken from the AeroCom dust benchmark (Huneeus et al., 2011).

count, which enhances the emissions from basins and valleys such as the Tigris-Euphrates region and the Afar Triangle, in better agreement with observations. Moreover, we have produced soil composition maps to differentiate the chemical composition of dust particles from different deserts that affects the coating of mineral dust by hygroscopic salts during atmospheric ageing.

The updated land cover classification, the inclusion of the topography factor and the modification of the sandblasting efficiency function have a considerable impact on the global and regional distributions of dust emissions. By comparison, the effect of the clay fraction and vegetation data updates is less distinct.

The updated input data, in combination with the adjustments to the emission scheme, improve the modelled AOD and DAOD, as demonstrated by the comparison with AERONET, MODIS and IASI observations. For this validation, we have evaluated the EMAC DAOD at wavelengths up to $10 \mu \mathrm{m}$ for the first time, which allows testing of the model with a focus on dust, i.e. based on IASI DAOD.

Also the comparison with dust deposition observations shows improved agreement when using the updated emissions. This is less clear for the comparison with dust concentration data, where original and updated emission schemes do not show a significant performance difference.

While the updates clearly improve the global distribution of aeolian dust, the total amount of globally emitted dust remains unchanged and consistent with literature values.

Subject to the future availability of suitable soil models in EMAC providing soil moisture values for a thin surface soil layer, the activation of the explicit soil moisture dependency of the threshold surface friction velocity might further improve the agreement with observed trends and variability.
Code and data availability. The Modular Earth Submodel System (MESSy) is continuously further developed and applied by a consortium of institutions. The usage of MESSy and access to the source code is licensed to all affiliates of institutions which are members of the MESSy Consortium. Institutions can become a member of the MESSy Consortium by signing the MESSy Memorandum of Understanding. More information can be found on the MESSy Consortium website (http://www.messy-interface.org, Messy Consortium, 2017). The input data files and all modifications to the EMAC source code presented in this article are available on request until they become part of the official MESSy code. 


\section{Appendix A: Emission equation}

In the DU_Astitha1 emission scheme (Astitha et al., 2012), the threshold surface friction velocity $u_{* \mathrm{t}}$ is obtained by the equation

$$
\begin{aligned}
u_{* \mathrm{t}}= & 0.129 \sqrt{\frac{D_{\mathrm{p}}}{\rho_{\text {air }}}\left(\rho_{\mathrm{p}} g+\frac{0.006 \mathrm{~g} \sqrt{\mathrm{cm}} / \mathrm{s}^{2}}{D_{\mathrm{p}}^{5 / 2}}\right)} \\
& \times\left\{\begin{array}{l}
\frac{1}{\sqrt{1.928 B^{0.092}-1}} \\
\left(1-0.0858 e^{-0.0617(B-10)}\right) \quad B \geq 10
\end{array}\right. \\
& \times\left(1-\frac{\ln \frac{z_{\mathrm{o}}}{z_{\mathrm{os}}}}{\ln \left(0.35\left(\frac{10 \mathrm{~cm}}{z_{\text {os }}}\right)^{0.8}\right)}\right)^{-1} \\
& \times \sqrt{1+1.21 \max \left(0,\left(w-\left(0.0014 \phi_{\text {clay }}^{2}+0.17 \phi_{\text {clay }}\right)\right)\right)^{0.68}},
\end{aligned}
$$

where

$$
\begin{aligned}
& D_{\mathrm{p}}=60 \mu \mathrm{m} \\
& \rho_{\text {air }} \\
& \rho_{\mathrm{p}}=2.65 \mathrm{~g} \mathrm{~cm}^{-3} \\
& g=9.80665 \mathrm{~m} \mathrm{~s}^{-2} \\
& B=\frac{u_{* t} D_{\mathrm{p}}}{v}
\end{aligned}
$$$$
v=0.157 \cdot 10^{-4} \mathrm{~m}^{-2} \mathrm{~s}^{-1}
$$$$
z_{\mathrm{o}}=0.01 \mathrm{~cm}
$$$$
z_{\mathrm{os}}=0.00333 \mathrm{~cm}
$$

$w$

$\phi_{\text {clay }}$ saltation particle diameter air density particle density gravitational acceleration friction Reynolds number, initially $B=$ $1331\left(D_{\mathrm{p}} / \mathrm{cm}\right)^{1.56}+0.38$ kinematic viscosity of air surface roughness length local roughness length of the uncovered surface gravimetric soil moisture in percent clay fraction in percent
The last soil moisture term in Eq. (A1) is omitted in the present study. If the surface friction velocity $u_{*}$ exceeds the threshold $u_{* \mathrm{t}}$, the resulting emission flux is computed according to the equation

$$
\begin{aligned}
j_{\mathrm{emis}, i}= & \frac{c \rho_{\mathrm{air}}}{g}\left(u_{*}+u_{* t}\right)^{2} \\
& \left(u_{*}-u_{* t}\right) 10^{-4} a f_{\text {landcover }} f_{\mathrm{veg}} M_{i},
\end{aligned}
$$

where

$$
\begin{aligned}
& i \\
& c=1 \\
& u_{*} \\
& f_{\text {landcover }} \\
& f_{\text {veg }}=1-\frac{\min (\text { LAI, } 0.35)}{0.35} \\
& a \\
& M_{i}
\end{aligned}
$$

mode index empirical constant (in this study $c=1.5$ ) surface friction velocity barren land fraction vegetation factor sandblasting efficiency mass fraction emitted into mode $i$

In the present study, we multiply the right-hand side of Eq. (A2) by the topography factor $S_{\text {topo }}=$ $\left(\left(z_{\max }-z\right) /\left(z_{\max }-z_{\min }\right)\right)^{5}$ defined in Eq. (3) and the corresponding normalisation factor $N=5.3$. In addition, the surface friction velocity $u_{*}$ is limited to a maximal value of $0.4 \mathrm{~m} \mathrm{~s}^{-1}$; i.e. $u_{*}$ in Eq. (A2) is replaced by $\min \left(u_{*}, 0.4 \mathrm{~m} \mathrm{~s}^{-1}\right)$. 
Supplement. The supplement related to this article is available online at: https://doi.org/10.5194/gmd-11-989-2018-supplement.

Competing interests. The authors declare that they have no conflict of interest.

Acknowledgements. The research reported in this publication has received funding from the King Abdullah University of Science and Technology (KAUST) CRG3 grant URF/1/2180-01 "Combined Radiative and Air Quality Effects of Anthropogenic Air Pollution and Dust over the Arabian Peninsula" and was supported by the European Space Agency as part of the Aerosol_cci project. Swen Metzger received funding from the European Commission through the H2020-EINFRA-2015-1 project "Energy oriented Centre of Excellence for computer applications (EoCoE)", proposal number 676629 .

The article processing charges for this open-access publication were covered by the Max Planck Society.

Edited by: Samuel Remy

Reviewed by: two anonymous referees

\section{References}

Abdelkader, M., Metzger, S., Mamouri, R. E., Astitha, M., Barrie, L., Levin, Z., and Lelieveld, J.: Dust-air pollution dynamics over the eastern Mediterranean, Atmos. Chem. Phys., 15, 9173-9189, https://doi.org/10.5194/acp-15-9173-2015, 2015.

Abdelkader, M., Metzger, S., Steil, B., Klingmüller, K., Tost, H., Pozzer, A., Stenchikov, G., Barrie, L., and Lelieveld, J.: Sensitivity of transatlantic dust transport to chemical aging and related atmospheric processes, Atmos. Chem. Phys., 17, 37993821, https://doi.org/10.5194/acp-17-3799-2017, 2017.

AERONET: available at: http://aeronet.gsfc.nasa.gov, last access: 31 August 2016.

Albani, S., Mahowald, N. M., Perry, A. T., Scanza, R. A., Zender, C. S., Heavens, N. G., Maggi, V., Kok, J. F., and OttoBliesner, B. L.: Improved dust representation in the Community Atmosphere Model, J. Adv. Model. Earth Sy., 6, 541-570, https://doi.org/10.1002/2013MS000279, 2014.

Allen, C. J. T., Washington, R., and Engelstaedter, S.: Dust emission and transport mechanisms in the central Sahara: Fennec ground-based observations from Bordj Badji Mokhtar, June 2011, J. Geophys. Res.-Atmos., 118, 6212-6232, https://doi.org/10.1002/jgrd.50534, 2013.

Allen, C. J. T., Washington, R., and Saci, A.: Dust detection from ground-based observations in the summer global dust maximum: Results from Fennec 2011 and 2012 and implications for modeling and field observations, J. Geophys. Res.-Atmos., 120, 897916, https://doi.org/10.1002/2014JD022655, 2015.

Anisimov, A., Tao, W., Stenchikov, G., Kalenderski, S., Prakash, P. J., Yang, Z.-L., and Shi, M.: Quantifying local-scale dust emission from the Arabian Red Sea coastal plain, Atmos. Chem. Phys., 17, 993-1015, https://doi.org/10.5194/acp-17-993-2017, 2017.
Astitha, M., Lelieveld, J., Abdel Kader, M., Pozzer, A., and de Meij, A.: Parameterization of dust emissions in the global atmospheric chemistry-climate model EMAC: impact of nudging and soil properties, Atmos. Chem. Phys., 12, 11057-11083, https://doi.org/10.5194/acp-12-11057-2012, 2012.

Balkanski, Y., Schulz, M., Claquin, T., Moulin, C., and Ginoux, P.: Global Emissions of Mineral Aerosol: Formulation and Validation using Satellite Imagery, Springer Netherlands, Dordrecht, 239-267, https://doi.org/10.1007/978-1-4020-2167-1_6, 2004.

Bonan, G. B., Levis, S., Kergoat, L., and Oleson, K. W.: Landscapes as patches of plant functional types: An integrating concept for climate and ecosystem models, Global Biogeochem. Cy., 16, 51-5-23, https://doi.org/10.1029/2000GB001360, 2002.

Brindley, H., Osipov, S., Bantges, R., Smirnov, A., Banks, J., Levy, R., Jish Prakash, P., and Stenchikov, G.: An assessment of the quality of aerosol retrievals over the Red Sea and evaluation of the climatological cloud-free dust direct radiative effect in the region, J. Geophys. Res.-Atmos., 120, 10862-10878, https://doi.org/10.1002/2015JD023282, 2015

Clerbaux, C., Boynard, A., Clarisse, L., George, M., Hadji-Lazaro, J., Herbin, H., Hurtmans, D., Pommier, M., Razavi, A., Turquety, S., Wespes, C., and Coheur, P.-F.: Monitoring of atmospheric composition using the thermal infrared IASI/MetOp sounder, Atmos. Chem. Phys., 9, 6041-6054, https://doi.org/10.5194/acp-96041-2009, 2009.

d'Almeida, G. A.: On the variability of desert aerosol radiative characteristics, J. Geophys. Res., 92, 3017, https://doi.org/10.1029/JD092iD03p03017, 1987.

Danielson, J. J. and Gesch, D. B.: Global Multi-resolution Terrain Elevation Data 2010 (GMTED2010), U.S. Geological Survey Open-File Report, available at: http://pubs.usgs.gov/of/2011/ 1073/pdf/of2011-1073.pdf (last access: 7 March 2018), 2011.

Darmenova, K., Sokolik, I. N., Shao, Y., Marticorena, B., and Bergametti, G.: Development of a physically based dust emission module within the Weather Research and Forecasting (WRF) model: Assessment of dust emission parameterizations and input parameters for source regions in Central and East Asia, J. Geophys. Res.-Atmos., 114, D14201, https://doi.org/10.1029/2008JD011236, 2009.

Dong, B. and Sutton, R.: Dominant role of greenhouse-gas forcing in the recovery of Sahel rainfall, Nat. Clim. Change, 5, 757-760, https://doi.org/10.1038/nclimate2664, 2015.

Fountoukis, C. and Nenes, A.: ISORROPIA II: a computationally efficient thermodynamic equilibrium model for $\mathrm{K}^{+}$ $\mathrm{Ca}^{2+}-\mathrm{Mg}^{2+}-\mathrm{NH}_{4}^{+}-\mathrm{Na}^{+}-\mathrm{SO}_{4}^{2-}-\mathrm{NO}_{3}^{-}-\mathrm{Cl}^{-}-\mathrm{H}_{2} \mathrm{O}$ aerosols, Atmos. Chem. Phys., 7, 4639-4659, https://doi.org/10.5194/acp-74639-2007, 2007.

Gherboudj, I., Beegum, S. N., Marticorena, B., and Ghedira, H.: Dust emission parameterization scheme over the MENA region: Sensitivity analysis to soil moisture and soil texture, J. Geophys. Res.-Atmos., 120, 10915-10938, https://doi.org/10.1002/2015JD023338, 2015.

Giannadaki, D., Pozzer, A., and Lelieveld, J.: Modeled global effects of airborne desert dust on air quality and premature mortality, Atmos. Chem. Phys., 14, 957-968, https://doi.org/10.5194/acp-14-957-2014, 2014.

Ginoux, P., Chin, M., Tegen, I., Prospero, J. M., Holben, B., Dubovik, O., and Lin, S.-J.: Sources and distributions of dust aerosols simulated with the GOCART 
model, J. Geophys. Res.-Atmos., 106, 20255-20273, https://doi.org/10.1029/2000JD000053, 2001.

Gläser, G., Kerkweg, A., and Wernli, H.: The Mineral Dust Cycle in EMAC 2.40: sensitivity to the spectral resolution and the dust emission scheme, Atmos. Chem. Phys., 12, 1611-1627, https://doi.org/10.5194/acp-12-1611-2012, 2012.

GMTED2010: available at: https://lta.cr.usgs.gov/GMTED2010 (last access: 24 August 2016), 2010.

Hilton, F., Armante, R., August, T., Barnet, C., Bouchard, A., Camy-Peyret, C., Capelle, V., Clarisse, L., Clerbaux, C., Coheur, P.-F., Collard, A., Crevoisier, C., Dufour, G., Edwards, D., Faijan, F., Fourrié, N., Gambacorta, A., Goldberg, M., Guidard, V., Hurtmans, D., Illingworth, S., Jacquinet-Husson, N., Kerzenmacher, T., Klaes, D., Lavanant, L., Masiello, G., Matricardi, M., McNally, A., Newman, S., Pavelin, E., Payan, S., Péquignot, E., Peyridieu, S., Phulpin, T., Remedios, J., Schlüssel, P., Serio, C., Strow, L., Stubenrauch, C., Taylor, J., Tobin, D., Wolf, W., and Zhou, D.: Hyperspectral Earth Observation from IASI: Five Years of Accomplishments, B. Am. Meteorol. Soc., 93, 347-370, https://doi.org/10.1175/BAMS-D-11-00027.1, 2012.

Holben, B., Eck, T., Slutsker, I., Tanré, D., Buis, J., Setzer, A., Vermote, E., Reagan, J., Kaufman, Y., Nakajima, T., Lavenu, F., Jankowiak, I., and Smirnov, A.: AERONET - A Federated Instrument Network and Data Archive for Aerosol Characterization, Remote Sens. Environ., 66, 1-16, https://doi.org/10.1016/S0034-4257(98)00031-5, 1998.

Hubanks, P., Platnick, S., King, M., and Ridgway, B.: MODIS Atmosphere L3 Gridded Product Algorithm Theoretical Basis Document (ATBD) \& Users Guide, 2015.

Huneeus, N., Schulz, M., Balkanski, Y., Griesfeller, J., Prospero, J., Kinne, S., Bauer, S., Boucher, O., Chin, M., Dentener, F., Diehl, T., Easter, R., Fillmore, D., Ghan, S., Ginoux, P., Grini, A., Horowitz, L., Koch, D., Krol, M. C., Landing, W., Liu, X., Mahowald, N., Miller, R., Morcrette, J.-J., Myhre, G., Penner, J., Perlwitz, J., Stier, P., Takemura, T., and Zender, C. S.: Global dust model intercomparison in AeroCom phase I, Atmos. Chem. Phys., 11, 7781-7816, https://doi.org/10.5194/acp11-7781-2011, 2011.

IASI: available at: http://www.esa-aerosol-cci.org/, last access: 31 August 2016.

IPCC: Climate Change 2013 - The Physical Science Basis, Cambridge University Press, https://doi.org/10.1017/CBO9781107415324, cambridge Books Online, 2014.

Jöckel, P., Sander, R., Kerkweg, A., Tost, H., and Lelieveld, J.: Technical Note: The Modular Earth Submodel System (MESSy) - a new approach towards Earth System Modeling, Atmos. Chem. Phys., 5, 433-444, https://doi.org/10.5194/acp-5-4332005, 2005.

Jöckel, P., Kerkweg, A., Pozzer, A., Sander, R., Tost, H., Riede, H., Baumgaertner, A., Gromov, S., and Kern, B.: Development cycle 2 of the Modular Earth Submodel System (MESSy2), Geosci. Model Dev., 3, 717-752, https://doi.org/10.5194/gmd-3717-2010, 2010.

Jones, S. L., Adams-Selin, R., Hunt, E. D., Creighton, G. A., and Cetola, J. D.: Update on modifications to WRF-CHEM GOCART for fine-scale dust forecasting at AFWA, AGU Fall Meeting Abstracts, 2012.
Karydis, V. A., Tsimpidi, A. P., Pozzer, A., Astitha, M., and Lelieveld, J.: Effects of mineral dust on global atmospheric nitrate concentrations, Atmos. Chem. Phys., 16, 1491-1509, https://doi.org/10.5194/acp-16-1491-2016, 2016.

Kergoat, L., Moulin, S., Cayrol, P., and Dedieu, G.: Controlling vegetation growth models with satellite measurements, in: Advances in environmental and ecological modelling, edited by: Blasco, F. and Weill, A., Elsevier Publishers, 73-89, 1999.

Klingmüller, K., Steil, B., Brühl, C., Tost, H., and Lelieveld, J.: Sensitivity of aerosol radiative effects to different mixing assumptions in the AEROPT 1.0 submodel of the EMAC atmosphericchemistry-climate model, Geosci. Model Dev., 7, 2503-2516, https://doi.org/10.5194/gmd-7-2503-2014, 2014.

Klingmüller, K., Pozzer, A., Metzger, S., Stenchikov, G. L., and Lelieveld, J.: Aerosol optical depth trend over the Middle East, Atmos. Chem. Phys., 16, 5063-5073, https://doi.org/10.5194/acp-16-5063-2016, 2016.

Klose, M., Shao, Y., Li, X., Zhang, H., Ishizuka, M., Mikami, M., and Leys, J. F.: Further development of a parameterization for convective turbulent dust emission and evaluation based on field observations, J. Geophys. Res.-Atmos., 119, 10441-10457, https://doi.org/10.1002/2014JD021688, 2014.

Kok, J. F., Mahowald, N. M., Fratini, G., Gillies, J. A., Ishizuka, M., Leys, J. F., Mikami, M., Park, M.-S., Park, S.-U., Van Pelt, R. S., and Zobeck, T. M.: An improved dust emission model - Part 1: Model description and comparison against measurements, Atmos. Chem. Phys., 14, 13023-13041, https://doi.org/10.5194/acp-14-13023-2014, 2014.

Lamchin, M., Lee, J.-Y., Lee, W.-K., Lee, E. J., Kim, M., Lim, C.-H., Choi, H.-A., and Kim, S.-R.: Assessment of land cover change and desertification using remote sensing technology in a local region of Mongolia, Adv. Space Res., 57, 64-77, https://doi.org/10.1016/j.asr.2015.10.006, 2016.

Laurent, B., Marticorena, B., Bergametti, G., Léon, J. F., and Mahowald, N. M.: Modeling mineral dust emissions from the Sahara desert using new surface properties and soil database, J. Geophys. Res.-Atmos., 113, d14218, https://doi.org/10.1029/2007JD009484, 2008.

Laurent, B., Tegen, I., Heinold, B., Schepanski, K., Weinzierl, B., and Esselborn, M.: A model study of Saharan dust emissions and distributions during the SAMUM-1 campaign, J. Geophys. Res.Atmos., 115, d21210, https://doi.org/10.1029/2009JD012995, 2010.

Levy, R. C., Mattoo, S., Munchak, L. A., Remer, L. A., Sayer, A. M., Patadia, F., and Hsu, N. C.: The Collection 6 MODIS aerosol products over land and ocean, Atmos. Meas. Tech., 6, 29893034, https://doi.org/10.5194/amt-6-2989-2013, 2013.

Mahowald, N., Kohfeld, K., Hansson, M., Balkanski, Y., Harrison, S. P., Prentice, I. C., Schulz, M., and Rodhe, H.: Dust sources and deposition during the last glacial maximum and current climate: A comparison of model results with paleodata from ice cores and marine sediments, J. Geophys. Res.-Atmos., 104, 15895-15916, https://doi.org/10.1029/1999JD900084, 1999.

Marsham, J. H., Hobby, M., Allen, C. J. T., Banks, J. R., Bart, M., Brooks, B. J., Cavazos-Guerra, C., Engelstaedter, S., Gascoyne, M., Lima, A. R., Martins, J. V., McQuaid, J. B., O'Leary, A., Ouchene, B., Ouladichir, A., Parker, D. J., Saci, A., Salah-Ferroudj, M., Todd, M. C., and Washington, R.: Meteorology and dust in the central Sahara: Observations 
from Fennec supersite-1 during the June 2011 Intensive Observation Period, J. Geophys. Res.-Atmos., 118, 4069-4089, https://doi.org/10.1002/jgrd.50211, 2013.

Marticorena, B. and Bergametti, G.: Modeling the atmospheric dust cycle: 1. Design of a soil-derived dust emission scheme, J. Geophys. Res., 100, 16415, https://doi.org/10.1029/95JD00690, 1995.

Marticorena, B., Bergametti, G., Aumont, B., Callot, Y., N'Doumé, C., and Legrand, M.: Modeling the atmospheric dust cycle: 2. Simulation of Saharan dust sources, J. Geophys. Res.-Atmos., 102, 4387-4404, https://doi.org/10.1029/96JD02964, 1997.

MESSy 2017: MESSy submodel list, available at: http://www. messy-interface.org/current/auto/messy_submodels.html, last access: 2 November 2017.

MESSy Consortium: MESSy licence conditions, available at: https: //www.messy-interface.org/current/messy_licence.html (last access: 7 March 2018), 2017.

Metzger, S., Mihalopoulos, N., and Lelieveld, J.: Importance of mineral cations and organics in gas-aerosol partitioning of reactive nitrogen compounds: case study based on MINOS results, Atmos. Chem. Phys., 6, 2549-2567, https://doi.org/10.5194/acp6-2549-2006, 2006.

Metzger, S., Steil, B., Abdelkader, M., Klingmüller, K., Xu, L., Penner, J. E., Fountoukis, C., Nenes, A., and Lelieveld, J.: Aerosol water parameterisation: a single parameter framework, Atmos. Chem. Phys., 16, 7213-7237, https://doi.org/10.5194/acp-167213-2016, 2016.

MODIS MCD12C1: available at: ftp://ladsweb.nascom.nasa.gov/ allData/51/MCD12C1/, last access: 9 June 2016.

MODIS MOD08 M3: available at: ftp://ladsweb.nascom.nasa.gov/ allData/6/MOD08_M3/, last access: 24 May 2017.

Natural Earth: available at: http://www.naturalearthdata.com, last access: 16 November 2016.

Olson, J.: World Ecosystems (WE1.4): Digital raster data on a 10 minute geographic 1080 × 2160 grid, in: Global Ecosystems Database, version 1.0, Disc A, NOAA National Geophysical Data Center, Boulder, Colorado, 1992.

Pantillon, F., Knippertz, P., Marsham, J. H., and Birch, C. E.: A Parameterization of Convective Dust Storms for Models with Mass-Flux Convection Schemes, J. Atmos. Sci., 72, 2545-2561, https://doi.org/10.1175/JAS-D-14-0341.1, 2015.

Pantillon, F., Knippertz, P., Marsham, J. H., Panitz, H.-J., and Bischoff-Gauss, I.: Modeling haboob dust storms in large-scale weather and climate models, J. Geophys. Res.-Atmos., 121, 2090-2109, https://doi.org/10.1002/2015JD024349, 2016.

Pérez, C., Nickovic, S., Baldasano, J. M., Sicard, M., Rocadenbosch, F., and Cachorro, V. E.: A long Saharan dust event over the western Mediterranean: Lidar, Sun photometer observations, and regional dust modeling, J. Geophys. Res.-Atmos., 111, d15214, https://doi.org/10.1029/2005JD006579, 2006.

Popp, T., de Leeuw, G., Bingen, C., Brühl, C., Capelle, V., Chedin, A., Clarisse, L., Dubovik, O., Grainger, R., Griesfeller, J., Heckel, A., Kinne, S., Klüser, L., Kosmale, M., Kolmonen, P., Lelli, L., Litvinov, P., Mei, L., North, P., Pinnock, S., Povey, A., Robert, C., Schulz, M., Sogacheva, L., Stebel, K., Stein Zweers, D., Thomas, G., Tilstra, L., Vandenbussche, S., Veefkind, P., Vountas, M., and Xue, Y.: Development, Production and Evaluation of Aerosol Climate Data Records from Euro- pean Satellite Observations (Aerosol_cci), Remote Sens., 8, 421, https://doi.org/10.3390/rs8050421, 2016.

Pozzer, A., de Meij, A., Yoon, J., Tost, H., Georgoulias, A. K., and Astitha, M.: AOD trends during 2001-2010 from observations and model simulations, Atmos. Chem. Phys., 15, 5521-5535, https://doi.org/10.5194/acp-15-5521-2015, 2015.

Pringle, K. J., Tost, H., Message, S., Steil, B., Giannadaki, D., Nenes, A., Fountoukis, C., Stier, P., Vignati, E., and Lelieveld, J.: Description and evaluation of GMXe: a new aerosol submodel for global simulations (v1), Geosci. Model Dev., 3, 391-412, https://doi.org/10.5194/gmd-3-391-2010, 2010a.

Pringle, K. J., Tost, H., Metzger, S., Steil, B., Giannadaki, D., Nenes, A., Fountoukis, C., Stier, P., Vignati, E., and Lelieveld, J.: Corrigendum to "Description and evaluation of GMXe: a new aerosol submodel for global simulations (v1)" published in Geosci. Model Dev., 3, 391-412, 2010, Geosci. Model Dev., 3 , 413-413, https://doi.org/10.5194/gmd-3-413-2010, 2010 b.

Sayer, A. M., Munchak, L. A., Hsu, N. C., Levy, R. C., Bettenhausen, C., and Jeong, M.-J.: MODIS Collection 6 aerosol products: Comparison between Aqua's e-Deep Blue, Dark Target, and "merged" data sets, and usage recommendations, J. Geophys. Res.-Atmos., 119, 13965-13989, https://doi.org/10.1002/2014JD022453, 2014.

Scholes, R. and Brown de Colstoun, E.: ISLSCP II Global Gridded Soil Characteristics, in: ISLSCP Initiative II Collection, edited by: Hall, F. G., Collatz, G., Meeson, B., Los, S., de Colstoun, E. B., and Landis, D., ORNL Distributed Active Archive Center, https://doi.org/10.3334/ORNLDAAC/1004, 2011.

Shangguan, W., Dai, Y., Duan, Q., Liu, B., and Yuan, H.: A global soil data set for earth system modeling, J. Adv. Model. Earth Sy., 6, 249-263, https://doi.org/10.1002/2013MS000293, 2014.

Shao, Y.: A model for mineral dust emission, J. Geophys. Res.-Atmos., 106, 20239-20254, https://doi.org/10.1029/2001JD900171, 2001.

Shao, Y., Wyrwoll, K.-H., Chappell, A., Huang, J., Lin, Z., McTainsh, G. H., Mikami, M., Tanaka, T. Y., Wang, X., and Yoon, S.: Dust cycle: An emerging core theme in Earth system science, Aeolian Res., 2, 181-204, https://doi.org/10.1016/j.aeolia.2011.02.001, 2011.

Shi, M., Yang, Z.-L., Stenchikov, G. L., Parajuli, S. P., Tao, W., and Kalenderski, S.: Quantifying the impacts of landscape heterogeneity and model resolution on dust emissions in the Arabian Peninsula, Environ. Model. Softw., 78, 106-119, https://doi.org/10.1016/j.envsoft.2015.12.021, 2016.

Solomos, S., Ansmann, A., Mamouri, R.-E., Binietoglou, I., Patlakas, P., Marinou, E., and Amiridis, V.: Remote sensing and modelling analysis of the extreme dust storm hitting the Middle East and eastern Mediterranean in September 2015, Atmos. Chem. Phys., 17, 4063-4079, https://doi.org/10.5194/acp17-4063-2017, 2017.

Spyrou, C., Mitsakou, C., Kallos, G., Louka, P., and Vlastou, G.: An improved limited area model for describing the dust cycle in the atmosphere, J. Geophys. Res.-Atmos., 115, d17211, https://doi.org/10.1029/2009JD013682, 2010.

Tanre, D., Geleyn, J.-F., and Slingo, J. M.: First results of the introduction of an advanced aerosol-radiation interaction in the ECMWF low resolution global model, in: Aerosols and their climatic effects, edited by: Gerber, H. and Deepak, A., A. Deepak Pub., 133-177, 1984. 
Taylor, K. E.: Summarizing multiple aspects of model performance in a single diagram, J. Geophys. Res.-Atmos., 106, 7183-7192, https://doi.org/10.1029/2000JD900719, 2001.

Tegen, I.: Impact of vegetation and preferential source areas on global dust aerosol: Results from a model study, J. Geophys. Res., 107, 4576, https://doi.org/10.1029/2001JD000963, 2002.

White, B. R.: Soil transport by winds on Mars, J. Geophys. Res., 84, 4643-4651, https://doi.org/10.1029/JB084iB09p04643, 1979.
Yuan, H., Dai, Y., Xiao, Z., Ji, D., and Shangguan, W.: Reprocessing the MODIS Leaf Area Index products for land surface and climate modelling, Remote Sens. Environ., 115, 1171-1187, https://doi.org/10.1016/j.rse.2011.01.001, 2011.

Zender, C. S., Bian, H., and Newman, D.: Mineral Dust Entrainment and Deposition (DEAD) model: Description and 1990s dust climatology, J. Geophys. Res.-Atmos., 108, 4416, https://doi.org/10.1029/2002JD002775, 2003. 